\title{
Productivity loss associated with functional disability in a contemporary small-scale subsistence population
}

\author{
Jonathan Stieglitz ${ }^{\mathrm{a}, b^{*}}$, Paul L. Hooper ${ }^{\mathrm{c}}$, Benjamin C. Trumble ${ }^{\mathrm{d}, \mathrm{e}}$, Hillard Kaplan ${ }^{\mathrm{c}}$, Michael D. \\ Gurven $^{\mathrm{f}}$ \\ *Corresponding author, at the following postal address: \\ Institute for Advanced Study in Toulouse \\ 1 esplanade de l'Université \\ T.470 \\ 31080 Toulouse Cedex 06, France \\ Phone: +33 624543057 \\ E-mail: jonathan.stieglitz@iast.fr
}

Author affiliations:

aUniversité Toulouse 1 Capitole, 1 esplanade de l'Université, 31080 Toulouse Cedex 06, France

bInstitute for Advanced Study in Toulouse, 1 esplanade de l'Université, 31080 Toulouse Cedex

06, France

'Economic Science Institute, Chapman University, 1 University Drive, Orange, CA, 92866, USA

${ }^{\mathrm{d} C}$ Center for Evolution and Medicine, Life Sciences C, 427 East Tyler Mall, Arizona State University, Tempe, AZ, 85281, USA

eSchool of Human Evolution and Social Change, 900 South Cady Mall, Arizona State

University, Tempe, AZ, 85281, USA

fDepartment of Anthropology, University of California, Santa Barbara, CA, 93106, USA

\section{Acknowledgements}

We thank the Tsimane for participating and THLHP personnel for collecting and coding data. We also thank the HORUS Study Team for assistance with CT data collection. Amélie Beaudet, George Perry, Susan Pfeiffer, Ian Wallace and two anonymous reviewers provided useful comments that improved the quality of the manuscript. Data on bone properties used in this study were generated under the supervision of Matthew Budoff. Funding was provided by the National Institutes of Health/National Institute on Aging (R01AG024119), National Science Foundation (1748282), the Center for Evolutionary Medicine at Arizona State University, and the University of California-Santa Barbara Academic Senate. JS acknowledges IAST funding from the French National Research Agency (ANR) under the Investments for the Future (Investissements d'Avenir) program, grant ANR-17-EURE-0010. Funding sources had no role in research conduct, study design or article preparation. 
medRxiv preprint doi: https://doi.org/10.1101/2020.09.10.20191916; this version posted November 23, 2020. The copyright holder for this preprint (which was not certified by peer review) is the author/funder, who has granted medRxiv a license to display the preprint in perpetuity.

It is made available under a CC-BY-NC-ND 4.0 International license .

46

47

48

49

50

51

52

53

54

55

56

57

58

59

60

61 Keywords: Functional disability; skeletal gracility; life history theory; vertebral fracture; bone

62

63

64

65

66

67

68

\section{Abstract}

In comparative cross-species perspective, humans experience unique physical impairments with potentially large consequences. Quantifying the burden of impairment in subsistence populations is critical for understanding selection pressures underlying strategies that minimize risk of production deficits. We examine among forager-horticulturalists whether compromised bone strength (indicated by fracture and lower bone mineral density, BMD) is associated with subsistence task cessation; we estimate the magnitude of productivity losses associated with compromised bone strength. Fracture is associated with cessation of hunting, tree chopping and walking long distances, but not tool manufacture. Age-specific productivity losses from hunting cessation associated with fracture and lower BMD are substantial: 397 lost kcals/day, with expected future losses of up to 1.9 million kcals (22\% of expected production). Productivity loss is thus substantial for high strength and endurance tasks. Determining the extent to which impairment obstructs productivity in contemporary subsistence populations improves our ability to infer past consequences of impairment.

mineral density; Tsimane 
medRxiv preprint doi: https://doi.org/10.1101/2020.09.10.20191916; this version posted November 23, 2020. The copyright holder for this

It is made available under a CC-BY-NC-ND 4.0 International license .

\section{Introduction}

As the longest living and slowest growing primate, humans experience unique physical impairments with potentially large economic and social consequences. Human hunter-gatherers have lower adult mortality than chimpanzees and a significant post-reproductive lifespan (Gurven and Kaplan 2007; Hill et al. 2007; Kaplan et al. 2010; Kaplan et al. 2000; Wood et al. 2017), which generates ample opportunity for incident degenerative disease and dysfunction (Finch 2010). Evidence of greater dietary reliance by hominins on difficult-to-acquire resources including hunted game at least 2 mya (Aiello and Wheeler 1995; Antón et al. 2014; Thompson et al. 2019; Ungar 2012) suggests delayed peak skill acquisition in adulthood (Gurven et al. 2006; Kaplan et al. 2000; Koster et al. 2019; Walker et al. 2002), possibly when senescence was already underway. Functional disability of degenerative origin may hinder hominin foraging in costly ways. These costs amplify if disability hinders resource transfers or provisioning of other assistance, given their potential fitness impacts (Gurven et al. 2012; Hawkes 2003; Hill and Hurtado 2009; Hooper et al. 2015; Marlowe 2003; Schniter et al. 2018; Wood and Marlowe 2013). The ubiquity among hunter-gatherers to form social groups of clusters of multigenerational resource-pooling units (Kaplan et al. 2009; Migliano et al. 2017), and in base camps at least $\sim 400$ kya (Kuhn and Stiner 2019), may reflect a species-typical strategy of complex cooperation to minimize daily risks, including production shortfalls. Quantifying the cost of disability in terms of productivity loss in extant small-scale subsistence populations is thus critical for understanding the strength of selection pressures for cooperative strategies that minimize risks associated with disability.

Skeletal evidence suggests that functional disability of degenerative origin may not have been that uncommon throughout hominin evolution, and that participation in activities essential 
medRxiv preprint doi: https://doi.org/10.1101/2020.09.10.20191916; this version posted November 23, 2020. The copyright holder for this preprint (which was not certified by peer review) is the author/funder, who has granted medRxiv a license to display the preprint in perpetuity.

It is made available under a CC-BY-NC-ND 4.0 International license .

92 for survival and reproduction (e.g. bipedal locomotion, food acquisition, load carrying) may have

93 been constrained by disability. For example, marked thoracic kyphosis and vertebral disc

94 degeneration are evident in Australopithecus afarensis (AL-288) from 3.2 mya (Cook et al.

95 1983), as is spondylolisthesis in middle Pleistocene humans (SH-1) from 430 kya ((Bonmatí et

96 al. 2010); also see (Trinkaus 2018)). These ailments regularly cause lower back pain, difficulty

97 walking, and carrying or lifting objects among modern clinical patients (Francis et al. 2008), who

98 may provide indirect insights into the consequences of disability in past hominin populations.

99 Given the variability across hominin species in terms of environmental exposures, diet, life

100 history traits (e.g. lifespan), morphology (e.g. body and brain size) and locomotion from 4 mya

101 until 40 kya (Wood and K. Boyle 2016), whether and how these impairments hindered survival

102 and reproduction is unclear, and not readily discernable from any single hominin species.

Joint behavioral and epidemiological study of contemporary small-scale subsistence

104 populations suggests that diverse impairments of degenerative or other etiology hinder resource

105 production and transfers. Among Yora forager-horticulturalists of Peru, men are unable to forage

106 due to illness or injury on $11 \%$ of all days (Sugiyama and Chacon 2000). Among Shiwiar

107 forager-horticulturalists of Ecuador, $>60 \%$ of individuals experience an impairment (e.g. chronic

108 pain, fracture, laceration, infection, animal bite or sting, burn) severe enough to interfere with

109 subsistence work for $\geq 1$ month; bone fractures - a focus of the current study - may be more

110 likely than other impairments to cause prolonged disability (Sugiyama 2004). Among Tsimane

111 forager-horticulturalists of Bolivia, the population studied here, $75 \%$ of adults report being

112 bedridden due to illness or injury at least once in the three months prior to survey, and Tsimane

113 are incapacitated on about 10\% of all days (Gurven et al. 2012). The fact that these studies 
114 include both younger and older adults (aged 20+ years) indicates that prolonged disability is not 115 conditional on reaching advanced ages.

While providing evidence that disability may have important consequences, the

117 observational studies of contemporary small-scale subsistence populations mentioned earlier are

118 limited: they rely mainly on self-reports and thus cannot identify objective, specific somatic

119 impairments associated with diminished subsistence effort; they utilize crude measures of

120 subsistence involvement (e.g. able to work or not) and thus cannot quantify the magnitude of

121 productivity loss or ascertain the range of subsistence behaviors associated with disability; they

122 often rely on small sample sizes of adults, including adults in their peak productive years; they

123 do not consider potential for bidirectional associations between somatic condition and economic

124 production; and they are not designed to isolate specific mechanisms linking somatic condition

125 and productivity. Precise assessment of the economic cost of disability and consideration of

126 potential compensatory strategies to mitigate disability-related productivity loss is important in

127 light of the comparatively low mortality rates characteristic of human life histories (Gurven and

128 Kaplan 2007). Studies of contemporary small-scale subsistence populations can thus

129 complement bio-archaeological and paleoanthropological studies for understanding factors

130 affecting foraging behavior and resilience in past hominin populations. In addition, in

131 populations lacking formal institutional mechanisms that minimize risks of economic insecurity

132 (e.g. workers' compensation, disability insurance) studies of the economic cost of disability are

133 important for understanding relationships between security, sociality, and well-being. As

134 subsistence populations like the Tsimane increasingly participate in local market economies,

135 studies of the economic cost of disability may also help inform policies designed to provide 136 social security benefits. 
medRxiv preprint doi: https://doi.org/10.1101/2020.09.10.20191916; this version posted November 23, 2020. The copyright holder for this preprint (which was not certified by peer review) is the author/funder, who has granted medRxiv a license to display the preprint in perpetuity.

It is made available under a CC-BY-NC-ND 4.0 International license .

Hominin social organization in multi-generational, multi-layered cooperative units are believed to be a necessary precursor for lowering mortality rates (Bird et al. 2019; Hawkes et al. 1998; Hill et al. 2007; Isaac 1978; Kaplan et al. 2000; Washburn and Lancaster 1968b). The fact that many subsistence skills require cumulative knowledge that is transmitted from older to younger generations implies that functionally disabled adults can maintain "fitness value," despite perhaps compromised ability to produce and transfer resources (Gurven et al. 2020b). How functional disability may have influenced behavior is unclear. Some anthropologists have interpreted human skeletal remains showing impairment as evidence of compassion and morality of group members, who presumably would have had to support the disabled (see (Dettwyler 1991) and references therein; (Tilley 2015)). This interpretation is contentious but supported by observations of modern hunter-gatherers frequently sharing food with impaired adults (e.g. Gurven et al. 2000). Ethnographic reports of death-hastening behaviors among frail elders (e.g. abandonment), who themselves may advocate such behaviors (e.g. (Balikci 1970)), suggests that decisions to support the disabled may be complex and influenced in part by their expected future productivity. Quantifying the economic cost of disability is therefore critical for understanding the extent of cooperation that must have co-evolved with hominin life history traits.

While there are diverse factors affecting functional ability, here we examine among Tsimane adults whether compromised bone strength is associated with diminished participation in routine subsistence tasks. We utilize thoracic computed tomography (CT) to measure two primary indicators of bone strength in thoracic vertebral bodies: bone mineral density (BMD), which accounts for $\sim 70 \%$ of the variance in bone strength (NIH Consensus Development Panel on Osteoporosis Prevention 2001), and fracture presence and severity. We focus on thoracic vertebrae for several reasons. Thoracic vertebral deformity is regularly observed in diverse 
medRxiv preprint doi: https://doi.org/10.1101/2020.09.10.20191916; this version posted November 23, 2020. The copyright holder for this preprint (which was not certified by peer review) is the author/funder, who has granted medRxiv a license to display the preprint in perpetuity.

It is made available under a CC-BY-NC-ND 4.0 International license .

160 hominin skeletal samples (Chapman 1972; Cook et al. 1983; Dequeker et al. 1997; Foldes et al.

161 1995; Gresky et al. 2016; Lieverse et al. 2007; Mays 1996; Trinkaus 1985). Thoracic vertebral

162 fractures are also among the most common fragility fractures in humans living in post-

163 industrialized populations (Sambrook and Cooper 2006), and are more common among Tsimane

164 compared to age- and sex-matched US (Los Angeles) controls (Stieglitz et al. 2019). While other

165 great apes experience degenerative disease (Jurmain 2000; Lovell 1990), spontaneous vertebral

166 fractures have not been observed in other apes, even in individuals with severe osteopenia (Gunji

167 et al. 2003). Bipedal hominins thus appear to be especially susceptible to fragility fractures of the

168 spine (Cotter et al. 2011) and perhaps other anatomical regions. Human thoracic vertebrae track

169 mechanics of both lower and upper limbs, and thoracic vertebral fracture can directly impede

170 mobility. Clinical vertebral deformities are commonly associated with pain and impaired quality

171 of life and can have serious long-lasting economic consequences (Francis et al. 2008). Declining

172 thoracic vertebral body BMD is a manifestation of senescence more generally, and rather than

173 directly inhibiting specific functional abilities per se, a co-occurrence of reduced BMD and

174 disability could indicate more general degenerative processes that do not necessarily involve

175 vertebral fracture (e.g. vertebral disc degeneration, osteophytes and nerve damage). Regardless

176 of the specific mechanisms, determining whether and how compromised thoracic vertebral

177 strength is associated with diminished productivity in an extant small-scale subsistence

178 population whose behavior can be directly studied improves the ability to infer more generally

179 potential economic cost of disability for an obligate biped reliant on extractive foraging and food 180 sharing.

In this paper we identify economic correlates of compromised bone strength (i.e. thoracic

182 vertebral body fracture and lower thoracic vertebral body BMD) by examining involvement in 
183 four common tasks in foraging economies: hunting, tree chopping, tool manufacture (i.e.

184 weaving), and walking long distances. These four tasks were selected because of their

185 importance in daily subsistence and their variation in strength and skill requirements. Hunting

186 has likely been an important source of hominin protein and fat production since early Homo

187 (Aiello and Wheeler 1995; Antón et al. 2014; Wrangham and Carmody 2010), and perhaps

188 earlier, although the dietary availability of meat and other animal products (e.g. marrow) in the

189 Plio-Pleistocene was variable across space and time. Tree chopping is essential for constructing

190 shelters and footbridges for water crossings, hunting arboreal or burrowing prey that hide in tree

191 trunks, manufacturing certain tools, gathering firewood and horticultural production. Tool

192 manufacture and repair has long improved extractive foraging efficiency for omnivorous,

193 manually dexterous hominins, as suggested by the fact that Oldowan tool-using hominins

194 absorbed energetic costs of transporting stones for processing carcasses over long distances (>10

$195 \mathrm{~km}$ ) (Braun et al. 2008). Weaving of items used for carrying diverse objects (e.g. woven bags

196 that store animal carcasses) and for resting (e.g. ground mats) is routinely performed by women

197 in numerous small-scale subsistence populations, including the Tsimane (Figure 1). Lastly, the

198 ability to efficiently travel long distances is evident for bipedal hominins relative to quadrupedal

199 apes by at least the mid-Pliocene (Pontzer et al. 2009); long-distance travel is crucial for

200 participating in diverse hominin foraging tasks (e.g. hunting, fishing) and in social activities (e.g.

201 visiting) within and across residential settlements.

202

203 Figure 1. Tsimane women weaving bags used for carrying diverse objects (left panel; photo

204 credit: Jonathan Stieglitz) and ground mats used for resting (right panel; photo credit: Arnulfo

205 Cary). Finished woven products are also shown in each panel. 


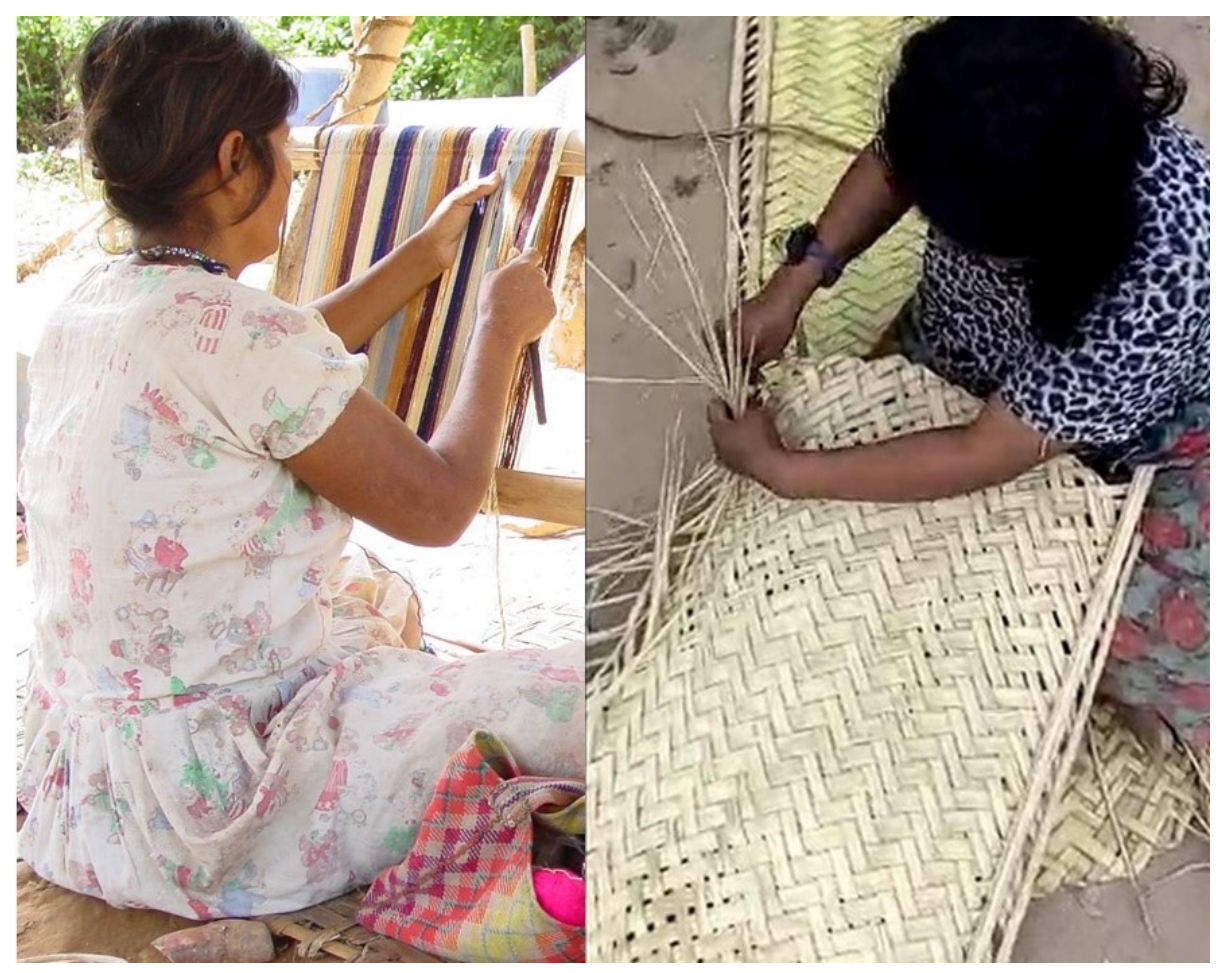
task increases with compromised bone strength. There are several possible explanations for how compromised bone strength may be associated with reduced economic productivity, and here we

212 focus on the mediating role of functional disability. One might expect considerable productivity 213 loss associated with compromised human thoracic vertebral body strength, as most activities of 214 daily living (e.g. sitting, walking, running, lifting and even breathing) generate vertebral loads 215 (Myers and Wilson 1997; Polga et al. 2004; Rohlmann et al. 2001; Stewart and Hall 2006). For many common activities (e.g. neutral standing, standing with weight, mild trunk flexion and

217 extension, lifting objects above the head) the greatest spinal compressive loads are generated in 218 the thoracolumbar region (Bruno et al. 2017). Compromised thoracic vertebral body strength 219 could especially curtail participation in high-strength and/or high-endurance tasks involving 
medRxiv preprint doi: https://doi.org/10.1101/2020.09.10.20191916; this version posted November 23, 2020. The copyright holder for this preprint (which was not certified by peer review) is the author/funder, who has granted medRxiv a license to display the preprint in perpetuity.

It is made available under a CC-BY-NC-ND 4.0 International license .

220 greater vertebral loads, such as hunting and tree chopping; participation in less physically

221 demanding tasks involving reduced vertebral loads, such as weaving, may not be strongly

222 curtailed. To the extent that men may more often participate in tasks requiring high levels of

223 strength and/or endurance in subsistence economies like that of the Tsimane with marked sexual

224 division of labor, compromised thoracic vertebral body strength could disproportionately hinder

225 male subsistence activities.

226

We next estimate the magnitude of productivity losses (i.e. lost kcals/day) from hunting

227 cessation associated with compromised bone strength. Productivity losses are estimated in two

228 ways: i) daily losses at age $x$; and 2) expected cumulative future losses from age $x$ onward, where

229 future losses are discounted by mortality. Substantial cumulative future productivity losses may

230 be expected from compromised vertebral body strength because trabecular bone losses during

231 adulthood are not fully regained (Mosekilde 1989; Mosekilde et al. 1987). Once spinal fracture

232 occurs it could impede daily subsistence activities for the remainder of life. We focus on hunting

233 productivity loss given the centrality of animal-based foods to theoretical models of hominin

234 behavioral and life history evolution (Bird et al. 2001; Hawkes et al. 2001; Hill and Hurtado

235 2009; Isaac 1978; Kaplan et al. 2000; Marlowe 2000; Washburn and Lancaster 1968a). Since

236 hominins as a taxonomic group show high plasticity in life history traits (e.g. expected adult

237 lifespan) and diet (e.g. reliance on meat), it is possible that our estimates of productivity loss

238 associated with compromised bone strength better approximate those for hominins with

239 relatively modern life histories. In the present context, hunting productivity losses refer to lost

240 hunting calories from hunting cessation associated with thoracic vertebral body fracture and/or

241 lower thoracic vertebral BMD. 
medRxiv preprint doi: https://doi.org/10.1101/2020.09.10.20191916; this version posted November 23, 2020. The copyright holder for this preprint (which was not certified by peer review) is the author/funder, who has granted medRxiv a license to display the preprint in perpetuity.

It is made available under a CC-BY-NC-ND 4.0 International license .

242

243

244

245

246

247

248

249

250

251

252

253

254

255

256

257

258

259

260

261

262

263

264

We do not assume ex ante that compromised bone strength per se is the only cause of disability or reduced productivity, or that these factors necessarily co-vary in some coordinated fashion-these are empirical questions partially addressed in this paper. We do expect that individuals with compromised bone strength who are no longer able to perform specific subsistence tasks will adjust their time allocation depending on various factors (e.g. own somatic condition, household demand). To gain insight into potential compensatory behavioral strategies of adults with compromised bone strength who can no longer hunt, we compare expected productivity losses from hunting to observed fishing production rates, as a means of ascertaining the degree of foraging modification required to offset disability-associated energetic deficits. This exercise provides insight into whether adults with compromised bone strength who cease hunting, through their own behavioral modifications, can easily retain their ability to provision themselves and kin with critical animal products in the diet, or whether provisioning by group members or other behavioral modifications may be necessary. Lastly, utilizing data on anthropometrics and self-reported reasons for ceasing to perform specific subsistence tasks, we examine whether compromised bone strength precedes task cessation, rather than the reverse.

\section{Methods}

\subsection{Study population}

Tsimane are semi-sedentary forager-horticulturalists inhabiting >90 villages in lowland Bolivia. Villages are usually located along rivers or other water sources (e.g. lagoons) and are composed of dispersed clusters of kin-related households. The household is the basic economic unit for production and consumption, and most daily coordination is confined to the nuclear and extended family. Tsimane hunt with a diverse toolkit that can include any/all of the following: 
medRxiv preprint doi: https://doi.org/10.1101/2020.09.10.20191916; this version posted November 23, 2020. The copyright holder for this preprint (which was not certified by peer review) is the author/funder, who has granted medRxiv a license to display the preprint in perpetuity.

It is made available under a CC-BY-NC-ND 4.0 International license .

265 rifle or shotgun (but guns and ammunition are often unavailable), bow and arrow, machete,

266 slingshot and trap, and sometimes assistance from tracking dogs (Gurven et al. 2006). On

267 average, men hunt about once every week or two; hunting is more common during the wet

268 season and in interior forest villages. The average hunt lasts 8.4 hours and covers $17.9 \mathrm{~km}$

269 (Trumble et al. 2014) and often involves carrying animal carcasses long distances. Tsimane

270 women occasionally hunt, much less often than men, and use different strategies with lower

271 return rates (e.g. women rarely use firearms). Because of women's relatively low participation in

272 hunting, we focus here only on men's hunting behavior. Fishing typically occurs in rivers,

273 streams or lagoons and involves use of hook-and-line, bow and arrow, machete, plant poison

274 and/or net. Single-day fishing and hunting activities are mostly solitary or in pairs with siblings,

275 sons, in-laws or age-mates. Entire families sometimes go on multi-day fishing and hunting trips

276 that can last from two days to several months. Food sharing is widespread within extended

277 families, but also limited in scope across families. Kinship and relative need largely determine

278 the magnitude and direction of food transfers (Gurven et al. 2012; Hooper et al. 2015).

Much of the protein and fat consumed by Tsimane come from hunting and fishing (Kraft

280 et al. 2018), whereas most (62\%) of the total calories in the diet come from cultigens grown in

281 small swiddens. In order to clear space for cultigens, machetes are first used to clear smaller

282 vegetation, and then metal axes (and more recently chainsaws when available) are used to cut

283 larger trees before planting and burning (Trumble et al. 2013). While both sexes plant cultigens,

284 help clear smaller vegetation and harvest, the felling of larger trees is typically done by men.

285 Women's physical activity level (PAL; defined as the ratio of total daily energy expenditure to

286 daily basal metabolism) is in the 'moderate to active' range (PAL=1.7-1.9) and is constant 
medRxiv preprint doi: https://doi.org/10.1101/2020.09.10.20191916; this version posted November 23, 2020. The copyright holder for this preprint (which was not certified by peer review) is the author/funder, who has granted medRxiv a license to display the preprint in perpetuity.

It is made available under a CC-BY-NC-ND 4.0 International license.

287 throughout adulthood. Men’s PAL is ‘vigorously active’ (PAL=2.0-2.2), and declines by 10-

$28820 \%$ from the peak (in the late 20s) to older adulthood (age 60+ years) (Gurven et al. 2013).

Physical strength peaks in the mid-to-late 20s, then declines thereafter, reaching $\sim 60 \%$ of maximum adult capacity by age 70 (Gurven et al. 2006). Impaired musculoskeletal function is not uncommon among Tsimane adults (see Figure 3H in (Gurven et al. 2020a)). BMD estimates

292 from the axial and appendicular skeleton - particularly from sites rich in trabecular bone (i.e.

293 thoracic vertebrae, calcaneus and distal radius) - suggest that osteoporosis is not uncommon, 294 especially for post-menopausal women (Stieglitz et al. 2015a; Stieglitz et al. 2016; Stieglitz et al. 295 2017; Stieglitz et al. 2019). Early and rapid reproduction may contribute to women’s skeletal 296 fragility later in life. Compared to more sedentary Los Angeles matched controls, age-

297 standardized prevalence of thoracic vertebral fracture is two times higher for Tsimane women 298 and 3.3 times higher for men using directly comparable CT methods (Stieglitz et al. 2019). For 299 adults age 50+, 38\% experience some movement restriction (e.g. during flexion or extension), 300 most commonly in the dorsolumbar, hip, knee or shoulder regions. Nearly $70 \%$ of adults age $50+$

301 are also clinically diagnosed with some condition of the musculoskeletal system and connective 302 tissue (i.e. codes M00-M99 using the International Classification of Diseases version 10) by 303 Tsimane Health and Life History Project (THLHP) physicians. By age 70 most adults report at 304 least some physical discomfort during activities of daily living (e.g. bathing).

\subsection{Study design and participants}

The Tsimane thoracic CT sample used to measure thoracic vertebral body BMD and 
range: 41-91 years, 48\% female, $\mathrm{n}=493$ ) (see Appendix for additional details and Appendix 1table 1 for descriptives of study variables). This CT sample is thought to be representative of all

312 Tsimane age 40+ years (see Appendix). Younger adults ( $<40$ years old) were excluded because

313 CT scans were performed as part of a broader project on atherosclerosis, including arterial

314 plaque formation, which is usually negligible at younger ages for physically active adults. No

315 Tsimane were excluded based on any health condition that can affect BMD or fracture risk. Institutional IRB approval was granted by UNM (HRRC \# 07-157) and UCSB (\# 3-160766), as was informed consent at three levels: (1) Tsimane government that oversees research projects, (2) village leadership, and (3) study participants.

\subsection{Thoracic computed tomography (CT)}

322 Bolivia using a 16-detector row scanner (GE Brightspeed, Milwaukee, WI, USA). A licensed

323 radiology technician acquired a single non-contrast thoracic scan, which was supervised and

324 reviewed by at least one of the HORUS study team cardiologists and radiologists with whom we

325 collaborate to study cardiovascular functioning (Kaplan et al. 2017). Breath-hold instructions

326 were given in the Tsimane language to minimize respiratory motion artifact and misregistration.

327 CT settings were: $250 \mathrm{~ms}$ exposure, $2.5 \mathrm{~mm}$ slice thickness, 0.5 s rotation speed, $120 \mathrm{kVp}$, and 32840 mA (see (Kaplan et al. 2017; Stieglitz et al. 2019) for additional details).

\subsection{Thoracic vertebral body bone mineral density (BMD)}


medRxiv preprint doi: https://doi.org/10.1101/2020.09.10.20191916; this version posted November 23, 2020. The copyright holder for this preprint (which was not certified by peer review) is the author/funder, who has granted medRxiv a license to display the preprint in perpetuity.

It is made available under a CC-BY-NC-ND 4.0 International license .

333 Thoracic vertebral body BMD was measured manually in each of three consecutive vertebrae

334 (T7-T10 range) by a radiologist with 20+ years of experience (see Appendix for additional

335 details). Lumbar vertebrae were not assessed as they did not appear in the CT image field of

336 view. BMD measurement started at the level of the section that contained the left main coronary

337 artery (LMCA) caudally (beginning at either T7 or T8, depending on the origin of the LMCA).

338 The LMCA was set as the reference site to allow reproducible detection of a spinal level;

339 because the LMCA is covered in 100\% of images and the field of view can be completely

340 reconstructed, it is an optimal reference point to locate the starting measurement level. The

341 LMCA has previously been found to originate at T7 about as frequently as T8 (Budoff et al.

342 2010).

343 The region of interest was located around the center of the vertebral body, with the edges

$344 \quad 2-3 \mathrm{~mm}$ from the vertebral shell. This distance ensured that vertebral body BMD measurements

345 excluded the cortical bone of the vertebral shell. For each vertebra, the radiologist manually

346 positioned a circular region of interest while demarcating cortical from trabecular bone based on

347 visual inspection. Any area with large vessels, bone island fractures and calcified herniated disks

348 were excluded as much as possible from the region of interest with use of the manual free tracing

349 protocol. Mean BMD for the three consecutive thoracic vertebrae was then calculated. This CT-

350 derived thoracic vertebral BMD measure is strongly positively correlated (Pearson r's $>0.9$ ) with

351 CT-derived lumbar vertebral BMD measures (Budoff et al. 2012). CT-derived BMD estimates

352 can be obtained with and without calibration phantoms. Phantomless BMD estimates correlate

353 strongly (Pearson r=0.99) with standard phantom-based CT BMD estimates (Budoff et al. 2013).

354 Hounsfield units were converted to BMD $\left(\mathrm{mg} / \mathrm{cm}^{3}\right)$ using a calibration phantom of known 
medRxiv preprint doi: https://doi.org/10.1101/2020.09.10.20191916; this version posted November 23, 2020. The copyright holder for this preprint (which was not certified by peer review) is the author/funder, who has granted medRxiv a license to display the preprint in perpetuity.

It is made available under a CC-BY-NC-ND 4.0 International license .

355 density, or a scanner-specific mean calibration factor for the T7-T10 vertebrae from scans

356 performed without the phantom.

357

358

\subsection{Thoracic vertebral body fracture}

359

For each individual the radiologist also classified seven vertebrae (T6-T12) according to

360 Genant’s semi-quantitative technique (GST) (Genant et al. 1993). While there is no consensus

361 regarding the radiologic definition of vertebral fracture, the GST provides highly reproducible

362 diagnosis of fractures, and is currently the most widely used clinical technique for identifying

363 and diagnosing fracture (Shepherd et al. 2015). Based on visual inspection, each vertebra is rated

364 according to severity of loss of vertebral height and other qualitative features, including

365 alterations in shape and configuration of the vertebra relative to adjacent vertebrae and expected

366 normal appearances. Each vertebra is classified into one of five categories: normal (grade 0);

367 mild fracture (grade 1; approximately 20-25\% reduction in anterior, middle, and/or posterior

368 vertebral height, and a 10-20\% reduction in projected vertebral area); moderate fracture (grade

3692 2; $25-40 \%$ reduction in any height and a $20-40 \%$ reduction in area); and severe fracture (grade

$3703 ;>40 \%$ reduction in any height and area). A grade 0.5 indicates borderline deformed vertebra

371 ( $<20 \%$ reduction in any height) that is not considered to be a definitive fracture (see Appendix

372 for additional details). Each individual is assigned one summary grade measure of all seven

373 vertebrae. Individuals with $>1$ vertebral deformity are classified according to their most severe

374 deformity. Individuals are considered to present fracture if any vertebral body is graded at least

375 mildly deformed (i.e. grade $\geq 1$ ); individuals are considered to present no fracture if graded 0 or

376 0.5. Given lower observer agreement for mild fractures (the most common) relative to moderate

377 and severe fractures (Lentle et al. 2018), we repeated some analyses using a more conservative 
medRxiv preprint doi: https://doi.org/10.1101/2020.09.10.20191916; this version posted November 23, 2020. The copyright holder for this preprint (which was not certified by peer review) is the author/funder, who has granted medRxiv a license to display the preprint in perpetuity.

It is made available under a CC-BY-NC-ND 4.0 International license .

378 fracture definition (i.e. grade $\geq 2$ ). Unless otherwise noted we report results using the former

379 definition.

380

381

2.6. Subsistence involvement and hunting productivity losses

382

A few days or weeks before traveling from their home villages to Trinidad for CT

383 scanning, study participants received in their villages a medical exam from a Bolivian physician

384 and bilingual (Spanish-Tsimane) physician assistant from the THLHP. During the medical exam,

385 participants were asked whether they continued or completely ceased involvement in routine

386 subsistence tasks (e.g. "Do you still hunt? Have you hunted in the past few months, or have you

387 stopped hunting altogether?”). Participants were queried about the following four tasks: hunting

388 (men only), tree chopping (men only), weaving (women only), and ability to walk an entire day

389 (both sexes) (also see (Stieglitz et al. 2015b)). Other subsistence tasks (e.g. fishing, collecting

390 fruit) were omitted due to time constraints during data collection. Women were not queried about

391 hunting or tree chopping (nor were men about weaving) because they rarely participate in these

392 tasks (Gurven et al. 2009). We were able to minimize assignment of “false negatives" (i.e.

393 coding capable participant $i$ as ceasing task $j$ due to a temporary illness which only inhibited $i$ 's

394 involvement in $j$ in the shorter but not longer term) by cross-checking participant response

395 stability over time using repeated measures from medical exams performed in other project years

396 (before and in a few cases after CT scanning; 98\% of CT study participants received at least one

397 medical exam in other [i.e. non-CT scanning] project years [mean \pm SD number of medical

398 exams/participant $=4 \pm 2, \min =1, \max =8]$ ). Responses were generally stable within individuals

399 over time, resulting in very few false negatives for a given task. If a participant reported ceasing

400 a given task in a given year, the physician then asked whether cessation resulted from specific 
401 functional limitations related to sensory perception (e.g. difficulty seeing or hearing), endurance 402 (e.g. feeling tired or weak), and mobility limitations (e.g. hip problems).

Population-level estimates of age-specific daily caloric production (total and task-specific

404 [e.g. hunting, fishing]) and time allocation have been published elsewhere (Gurven et al. 2012;

405 Gurven et al. 2009; Hooper 2011; Hooper et al. 2014; Hooper et al. 2015; Kaplan et al. 2010;

406 Schniter et al. 2015; Stieglitz et al. 2014). Briefly, Tsimane production was estimated by

407 interviewing adults once or twice per week from January 2005-December 2009 about time

408 allocation and production for each co-resident individual over age six during the previous two

409 days ( $n=1,245$ individuals from 11 villages). Each family was interviewed an average of 46 times

410 (SD=20), yielding an average of 93 sample days per individual. Each co-resident individual

411 contributes production data, regardless of their BMD or fracture status (which was unknown at

412 the time of economic data collection); thus, from individual-level production data we cannot

413 determine whether adults with fracture or lower BMD have lower production efficiency (e.g.

414 kcals/hour) than adults without fracture or higher BMD.

To estimate men's hunting productivity losses associated with fracture and lower BMD,

416 we multiply men's average age-specific daily hunting production by the probability that men still

417 hunt at a given age. This probability that men still hunt is modeled using binary logistic

418 regression with the following covariates: age (years), fracture status (yes/no) and BMD (mg/ $\mathrm{cm}^{3}$;

419 also see Appendix). This probability thus serves as a multiplier adjusting men’s average daily

420 hunting production for disability associated with fracture and lower BMD. To determine

421 productivity loss we take the difference in estimated hunting kcals/day at each age for a given

422 fracture and/or BMD value. For example, if a 40 year-old produces 2,000 hunting kcals/day, and

423 if the probability that a 40 year-old without fracture still hunts is 0.99 (vs. 0.85 for a 40 year-old 
424 with fracture), then the predicted hunting production is 1,980 kcals/day for a 40 year-old without

425 fracture (i.e. 2,000*0.99), and 1,700 kcals/day for a 40 year-old with fracture (i.e. 2,000*0.85;

426 productivity loss=280 hunting kcals/day). Similarly, if a 50 year-old produces 1,800 hunting

427 kcals/day, and if the probability that a 50 year-old without fracture still hunts is 0.9 (vs. 0.75 for

428 a 50 year-old with fracture), then the predicted hunting production is 1,620 kcals/day for a 50

429 year-old without fracture and 1,350 kcals/day for a 50 year-old with fracture (productivity

430 loss=270 hunting kcals/day; i.e. 10 fewer daily lost kcals compared to age 40). We assume that

431 hunting return rates (i.e. kcals/hour hunting) are identical for men regardless of fracture status or

432 BMD. Since we do not assume reduced hunting efficiency for men with fracture or lower BMD,

433 the productivity losses reported here may be conservative, and result entirely from complete

434 hunting cessation. This hunting productivity loss is our estimate of the economic cost associated

435 with fracture and lower BMD. We estimate this cost in two ways: 1) daily loss at age $x$, as in the

436 prior example of a 40 and 50 year-old; and 2) expected cumulative future losses from age $x$

437 onward, where future losses are discounted by mortality. Conceptually, this latter value is similar

438 to Fisher’s reproductive value (expected future reproduction at each age) but substitutes age-

439 specific fertility with age-specific caloric production from hunting, given Tsimane population

440 age structure and men’s mortality rates (Gurven et al. 2012).

441

442 2.7. Socio-demographics and anthropometrics

443 Birth years were assigned based on a combination of methods described elsewhere (see

444 Appendix for additional details). Height and weight were measured during THLHP medical

445 exams using a Seca portable stadiometer and Tanita scale. The scale uses bioelectrical

446 impedance to estimate body fat percentage using proprietary estimation equations. Using weight 
medRxiv preprint doi: https://doi.org/10.1101/2020.09.10.20191916; this version posted November 23, 2020. The copyright holder for this preprint (which was not certified by peer review) is the author/funder, who has granted medRxiv a license to display the preprint in perpetuity.

It is made available under a CC-BY-NC-ND 4.0 International license .

447 and percent body fat we calculated fat mass (weight*percent body fat) and fat-free mass (weight

448 - fat mass).

449

450

\subsection{Data analysis}

451

In descriptive analyses (section 3.1) we report fracture prevalence for each sex and test

452 for effects of age and BMD on fracture risk using log-binomial generalized linear models. Chi-

453 squared tests are used to compare differences in subsistence participation (e.g. whether

454 continuing or completely ceasing hunting or tree chopping) by fracture status (sections 3.2 and

455 3.4-3.6). Binary logistic regression is used to model the probability of subsistence task cessation

456 as a function of fracture status and BMD after adjusting for age. We use stepwise regression with

457 fracture status included first, and then BMD, and we compare models based on AIC. False

458 discovery rate (FDR) q-values were computed using the R package 'qvalue' to account for the

459 multiple testing burden across different subsistence tasks. Parameter estimates are reported as

460 odds ratios (ORs) or predicted probabilities.

461 We apply several indirect methods for assessing reverse causality, whereby ceasing task

462 performance leads to compromised bone strength ${ }^{1}$ (section 3.7). First, we use chi-squared tests to

463 compare differences by fracture status in self-reported reasons for subsistence task cessation,

464 including deficits in sensory perception, strength, endurance and mobility. If fractures cause task

465 cessation, then those with fractures should be more likely to report mobility limitations as a main

466 reason for task cessation, rather than other reasons. Second, we use general linear models to

467 compare BMD of adults who continue vs. cease task participation (adjusting for age and fat-free

468 mass). This comparison helps determine whether adults who cease participation experience

\footnotetext{
${ }^{1}$ We cannot determine from the CT scan or any other THLHP data when fracture occurred.
} 
medRxiv preprint doi: https://doi.org/10.1101/2020.09.10.20191916; this version posted November 23, 2020. The copyright holder for this preprint (which was not certified by peer review) is the author/funder, who has granted medRxiv a license to display the preprint in perpetuity.

It is made available under a CC-BY-NC-ND 4.0 International license .

469 greater risk of skeletal fragility overall. Lastly, for reasons described below, we test for a

470 mediating effect of anthropometric status in logistic regressions of task cessation on fracture

471 status and BMD. For all analyses we use $\alpha=0.05$ as the cutoff for statistical significance (we

472 report both p-values and FDR q-values where relevant). Participants with any missing values are

473 removed from analyses. Data that support the findings of this study are available on Dryad

474 (https://doi.org/10.5061/dryad.h44j0zphj).

475

476 3. Results

477 3.1. Descriptives: thoracic vertebral body fracture prevalence and covariation with age and

478 thoracic vertebral body BMD

479 3.1.1. Men. Prevalence of any thoracic vertebral body fracture (i.e. grade $\geq 1$; including mild, 480 moderate or severe) for men aged 40+ years is 36\% (95\% CI: 30-42) (Figure 2). Using a more

481 conservative fracture definition (i.e. grade $\geq 2$; including only moderate or severe), men’s

482 prevalence is $11 \%$ (95\% CI: 7-15). Neither men’s age nor thoracic vertebral body BMD is

483 significantly associated with fracture risk (Figure 2), regardless of fracture grade.

484

485 Figure 2. Top: Proportion of Tsimane men with thoracic vertebral body fracture (grade $\geq 1$ ) by

486 age, estimated using the loess function. The shaded region shows $\pm 1 \mathrm{SE}$, and jittered data points

487 represent fracture status. Bottom: scatterplot of thoracic vertebral body BMD by age and fracture

488 status, including linear regression lines for each fracture status. $\mathrm{N}=256$ men. 

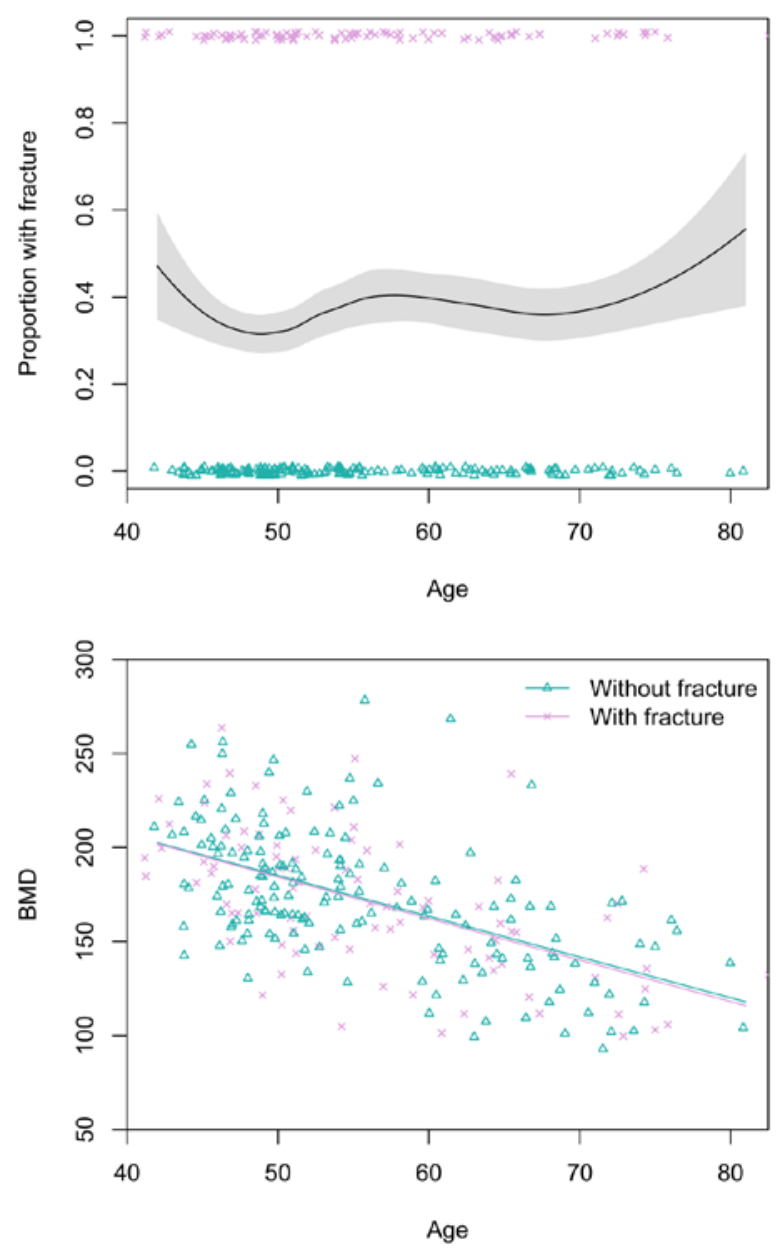

491 14-24) (Figure 3). Women’s grade 2 fracture prevalence is 7\% (95\% CI: 4-10). Women’s age

492 does not significantly predict fracture risk in univariate models, regardless of fracture grade.

493 BMD is inversely associated with women’s fracture risk after adjusting for age (grade 1: adjusted

494 relative risk $\mathrm{BMD}_{\mathrm{B} \text { per } \mathrm{SD} \text { increase }}=0.49,95 \% \mathrm{CI}$ : 0.34-0.72, $\mathrm{p}<0.001$; grade 2 : adjusted relative risk $\mathrm{BMD}_{\mathrm{B}}$

495 per SD increase $=0.25,95 \%$ CI: $0.11-0.57, p=0.001$; see Figure 3); in both of these models that include

496 BMD as a covariate, age is inversely and significantly associated with fracture risk. 
medRxiv preprint doi: https://doi.org/10.1101/2020.09.10.20191916; this version posted November 23, 2020. The copyright holder for this preprint (which was not certified by peer review) is the author/funder, who has granted medRxiv a license to display the preprint in perpetuity. It is made available under a CC-BY-NC-ND 4.0 International license .

499 Figure 3. Top: Proportion of Tsimane women with thoracic vertebral body fracture (grade $\geq 1$ ) by 500 age, estimated using the loess function. The shaded region shows $\pm 1 \mathrm{SE}$, and jittered data points 501 represent fracture status. Bottom: scatterplot of thoracic vertebral body BMD by age and fracture 502 status, including linear regression lines for each fracture status. N=237 women.
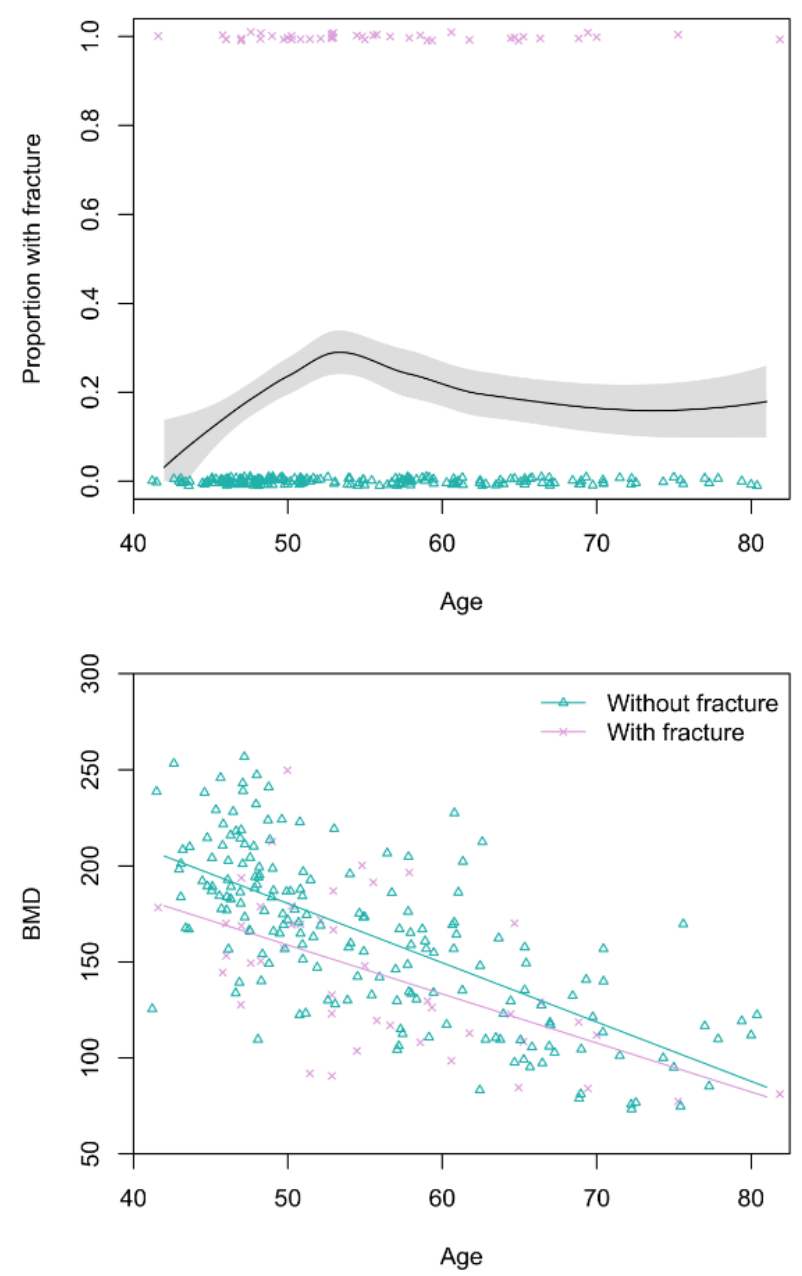
medRxiv preprint doi: https://doi.org/10.1101/2020.09.10.20191916; this version posted November 23, 2020. The copyright holder for this preprint (which was not certified by peer review) is the author/funder, who has granted medRxiv a license to display the preprint in perpetuity.

It is made available under a CC-BY-NC-ND 4.0 International license .

508 with no fracture (Table 1). After adjusting for age, odds of hunting cessation are 7.3 times

509 greater (95\% CI: 3.3-17.6, $\mathrm{p}<0.001$, FDR $\mathrm{q}<0.001, \mathrm{n}=256)$ for men with vs. without fracture

510 (Appendix 1-table 3: Model 1). The association between odds of hunting cessation and fracture

511 increases slightly (adjusted $\mathrm{OR}_{\text {Fracture }}=7.4$ ) after also including thoracic vertebral body BMD as a

512 covariate (adjusted OR ${ }_{\mathrm{BMD} \text { per } \mathrm{SD}}=0.62$, 95\% CI: 0.38-0.99, p=0.054, FDR q=0.161, Appendix 1-

513 table 3: Model 2).

516 Table 1. Percentage of men (95\% CI) who completely ceased hunting by age and thoracic

517 vertebral body fracture status.

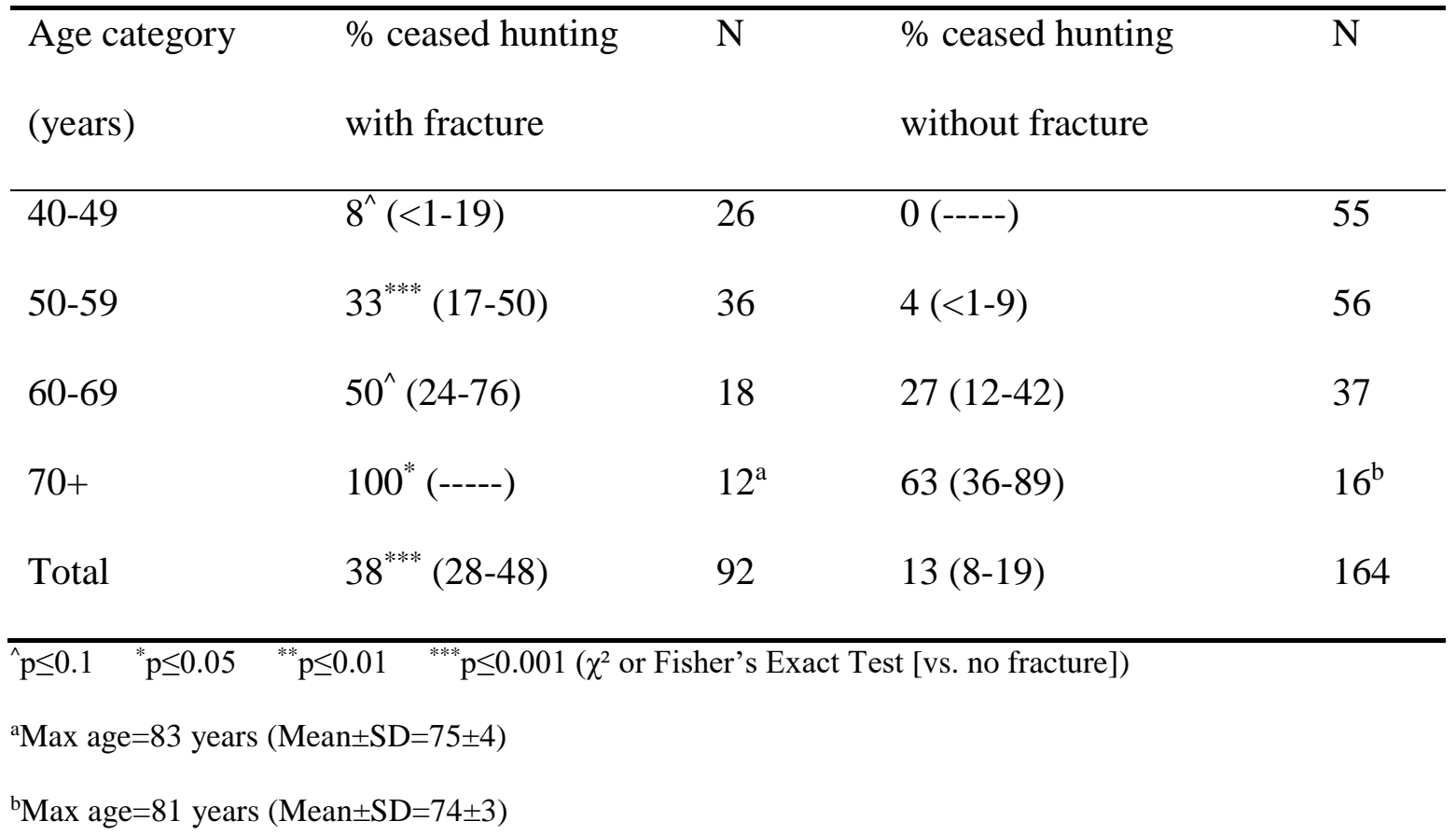

\footnotetext{
${ }^{2}$ Results are similar using a more conservative fracture definition (i.e. grade $\geq 2$; see Appendix 1-table 2).

Subsequently we only present results where fracture grade $\geq 1$.
} 
medRxiv preprint doi: https://doi.org/10.1101/2020.09.10.20191916; this version posted November 23, 2020. The copyright holder for this preprint (which was not certified by peer review) is the author/funder, who has granted medRxiv a license to display the preprint in perpetuity.

It is made available under a CC-BY-NC-ND 4.0 International license .

521

522

523

524

525

526

527

528

529

530

531

532

533

534

535

536

537

538

539

540

541

\subsection{Hunting cessation associated with thoracic vertebral body fracture and lower BMD} generates substantial productivity losses

3.3.1. Fracture. Figure 4 shows men's age-specific hunting productivity by fracture status (see Appendix 1-table 4 for raw production values and additional details). Men with fracture underproduce to a lesser extent at younger vs. older ages because of high hunting participation rates by younger men regardless of fracture status (Table 1, Appendix 1-table 2). As hunting cessation becomes increasingly likely with age, particularly for men with fracture, daily productivity losses associated with fracture (i.e. the hunting productivity differential for men with vs. without fracture) increase until age 61, when men with fracture produce 481 fewer hunting kcals/day than men without fracture (1,007 vs. $526 \mathrm{kcals} /$ day, respectively). This loss of $481 \mathrm{kcals} / \mathrm{day}-$ the equivalent of 120 grams of protein (or 53 grams of fat) - represents $19 \%$ of the mean daily per-capita energy intake for a Tsimane man that age (2,592 kcals), and 52\% of the mean intake from protein and fat (919 kcals). By comparison, this loss of 481 hunting kcals/day at age 61 exceeds daily fishing production at that age by $171 \mathrm{kcals}^{3}$ (Figure 4). Daily hunting productivity losses associated with fracture exceed fishing productivity for 14 years, from ages 55-68 (by 29$171 \mathrm{kcals} /$ day). In this same age range, based on observed age-specific return rates and time allocation, to wholly offset hunting productivity losses a Tsimane man would have to fish an additional 51-76 mins/day (e.g. from an observed 49 to an expected 125 fishing mins/day at age $61^{4}$; an increase of 155\%). As men's hunting participation rates decline with age regardless of fracture status, hunting productivity losses associated with fracture also decline, reaching zero by age 75 (when hunting returns reach zero; Figure 4).

\footnotetext{
${ }^{3}$ Based on men's observed age-specific daily fishing production (see Methods).

${ }^{4}$ Assuming identical fishing return rates regardless of fracture status and BMD (see Methods).
} 
medRxiv preprint doi: https://doi.org/10.1101/2020.09.10.20191916; this version posted November 23, 2020. The copyright holder for this preprint (which was not certified by peer review) is the author/funder, who has granted medRxiv a license to display the preprint in perpetuity.

It is made available under a CC-BY-NC-ND 4.0 International license .

Figure 4 also shows expected cumulative future productivity over the rest of life from a

543 specific age onward, discounted by mortality. Future productivity losses associated with fracture

544 (i.e. the hunting productivity differential for men with vs. without fracture) peak at age 40, when

545 men with fracture can expect to lose 1.15 million kcals over their remaining life; at that age, this

546 loss represents $14 \%$ of men's total future hunting production (8.49 million kcals). Future hunting

547 productivity losses associated with fracture exceed future fishing productivity for 16 years, from

548 ages 49-64 (by 2-32\% [or 4,772-96,419 expected cumulative future kcals]; Figure 4). In this

549 same age range, based on the maximum observed fishing return rate ${ }^{5}$ (420 kcals/hr at age 49)

550 and observed age-specific time allocation (e.g. 53 fishing mins/day at age 49), to wholly offset

551 future hunting productivity losses associated with fracture a Tsimane man would have to fish an

552 additional 258-1,780 hours (i.e. 324-2,012 additional future fishing days).

553

554 Figure 4. Top: Age-specific productivity (kcals/day) for hunting by men’s fracture status, and for

555 fishing (all men). Bottom: expected cumulative future productivity (millions of kcals) from age $x$

556 onward, discounted by mortality, for hunting by men’s fracture status, and for fishing (all men).

\footnotetext{
${ }^{5}$ We apply the maximum observed return rate to derive a conservative estimate. If instead we apply the minimum rate (360 kcals/hr at age 64), then to wholly offset future hunting productivity losses associated with fracture a man would have to fish an additional 302-2,076 hours (i.e. 378-2,347 additional future fishing days).
} 
medRxiv preprint doi: https://doi.org/10.1101/2020.09.10.20191916; this version posted November 23, 2020. The copyright holder for this preprint (which was not certified by peer review) is the author/funder, who has granted medRxiv a license to display the preprint in perpetuity.

It is made available under a CC-BY-NC-ND 4.0 International license .
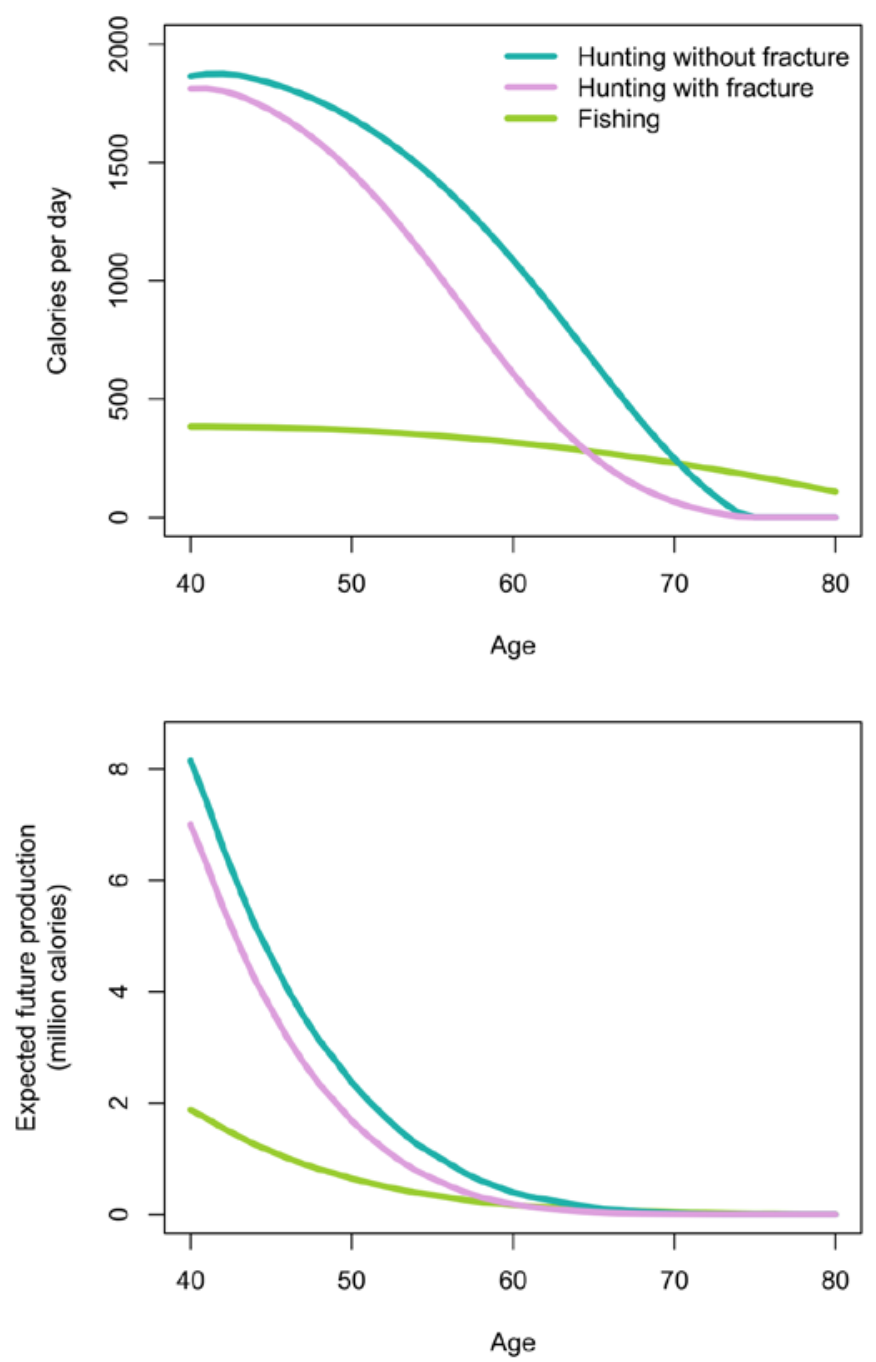

557

558

559 3.3.2. Lower BMD. We now estimate additional productivity losses (again expressed as the

560 hunting productivity differential) associated with having lower BMD. Losses are greatest for

561 men with fracture and lower BMD vs. men without fracture and higher BMD (Figure 5; see

562 Appendix 1-table 5 for raw production values and additional details). In this case, peak losses at

563 a given age (age 60: $650 \mathrm{kcals} /$ day - the equivalent of 163 grams of protein [or 72 grams of fat])

564 represent $25 \%$ of the mean daily per-capita energy intake for a Tsimane man that age and $70 \%$ of

565 the mean intake from protein and fat. By comparison, this loss of 650 hunting kcals/day at age 60 
medRxiv preprint doi: https://doi.org/10.1101/2020.09.10.20191916; this version posted November 23, 2020. The copyright holder for this preprint (which was not certified by peer review) is the author/funder, who has granted medRxiv a license to display the preprint in perpetuity.

It is made available under a CC-BY-NC-ND 4.0 International license .

566

567

568

569

570

571

572

573

574

575

576

577

578

579

580

581

582

583

584

exceeds daily fishing production at that age by 333 kcals $^{3}$. Hunting productivity losses for men with fracture and lower BMD (vs. men without fracture and higher BMD) exceed fishing productivity for 21 years, from ages 50-70 (by 33-335 kcals/day). In this same age range, based on observed age-specific return rates and time allocation, to wholly offset hunting productivity losses a Tsimane man would have to fish an additional 54-102 mins/day (e.g. from an observed 49 to an expected 151 fishing mins/day at age $60^{4}$; an increase of 205\%). Hunting productivity losses are smallest for men without fracture and higher vs. lower BMD (max=136 kcals/day at age 65; Figure 5).

Expected cumulative future losses are also greatest for men with fracture and lower BMD vs. men without fracture and higher BMD (Figure 5). At the peak (age 40) the former are expected to produce 1.88 million fewer future hunting kcals than the latter. At that age this loss represents $22 \%$ of men's total future hunting production. Future hunting productivity losses for men with fracture and lower BMD vs. men without fracture and higher BMD exceed future fishing productivity for 28 years, from ages 40-67 (by 0.1-81\% [or 1,193-383,902 expected cumulative future kcals]). In this same age range, based on the maximum observed fishing return rate $^{6}$ and observed age-specific time allocation, to wholly offset future hunting productivity losses a Tsimane man would have to fish an additional 160-4,443 hours (i.e. 207-4,849 additional future fishing days).

\footnotetext{
${ }^{6}$ We apply the maximum observed return rate to derive a conservative estimate. If instead we apply the minimum rate, then to wholly offset future hunting productivity losses a man would have to fish an additional 202-5,594 hours (i.e. 261-6,105 additional future fishing days).
} 
medRxiv preprint doi: https://doi.org/10.1101/2020.09.10.20191916; this version posted November 23, 2020. The copyright holder for this preprint (which was not certified by peer review) is the author/funder, who has granted medRxiv a license to display the preprint in perpetuity.

It is made available under a CC-BY-NC-ND 4.0 International license .

585 Figure 5. Top: Age-specific productivity (kcals/day) for hunting by men’s fracture status and

586 bone mineral density (BMD), and for fishing (all men). For illustrative purposes we show daily

587 hunting production for men with +1 SD and -1 SD of the BMD mean. Bottom: expected

588 cumulative future productivity (millions of kcals) from age $x$ onward, discounted by mortality,

589 for hunting by men’s fracture status and BMD, and for fishing (all men).
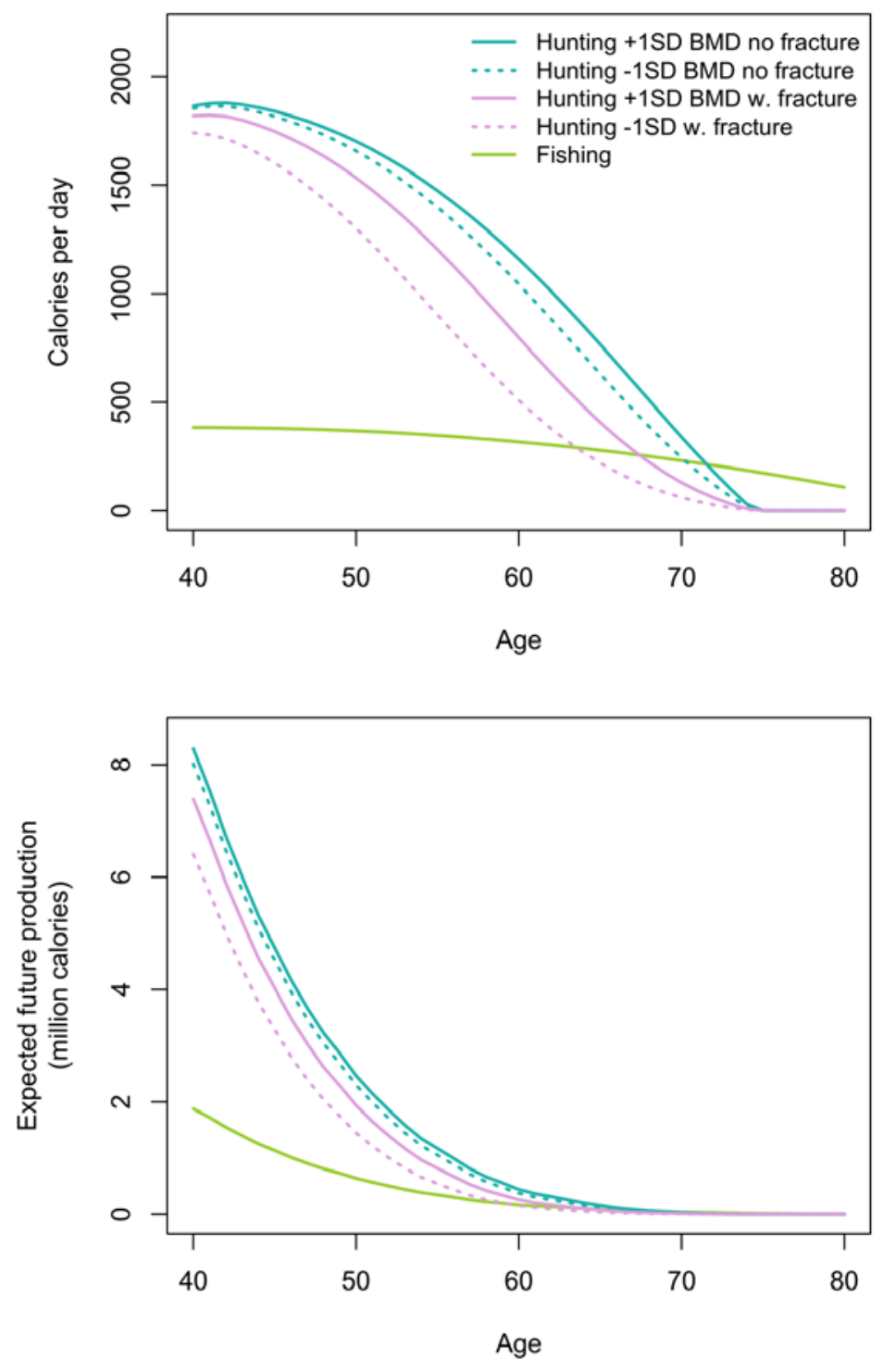
medRxiv preprint doi: https://doi.org/10.1101/2020.09.10.20191916; this version posted November 23, 2020. The copyright holder for this preprint (which was not certified by peer review) is the author/funder, who has granted medRxiv a license to display the preprint in perpetuity.

It is made available under a CC-BY-NC-ND 4.0 International license .

593

594

595

596

597

598

599

600

601

602

603

604

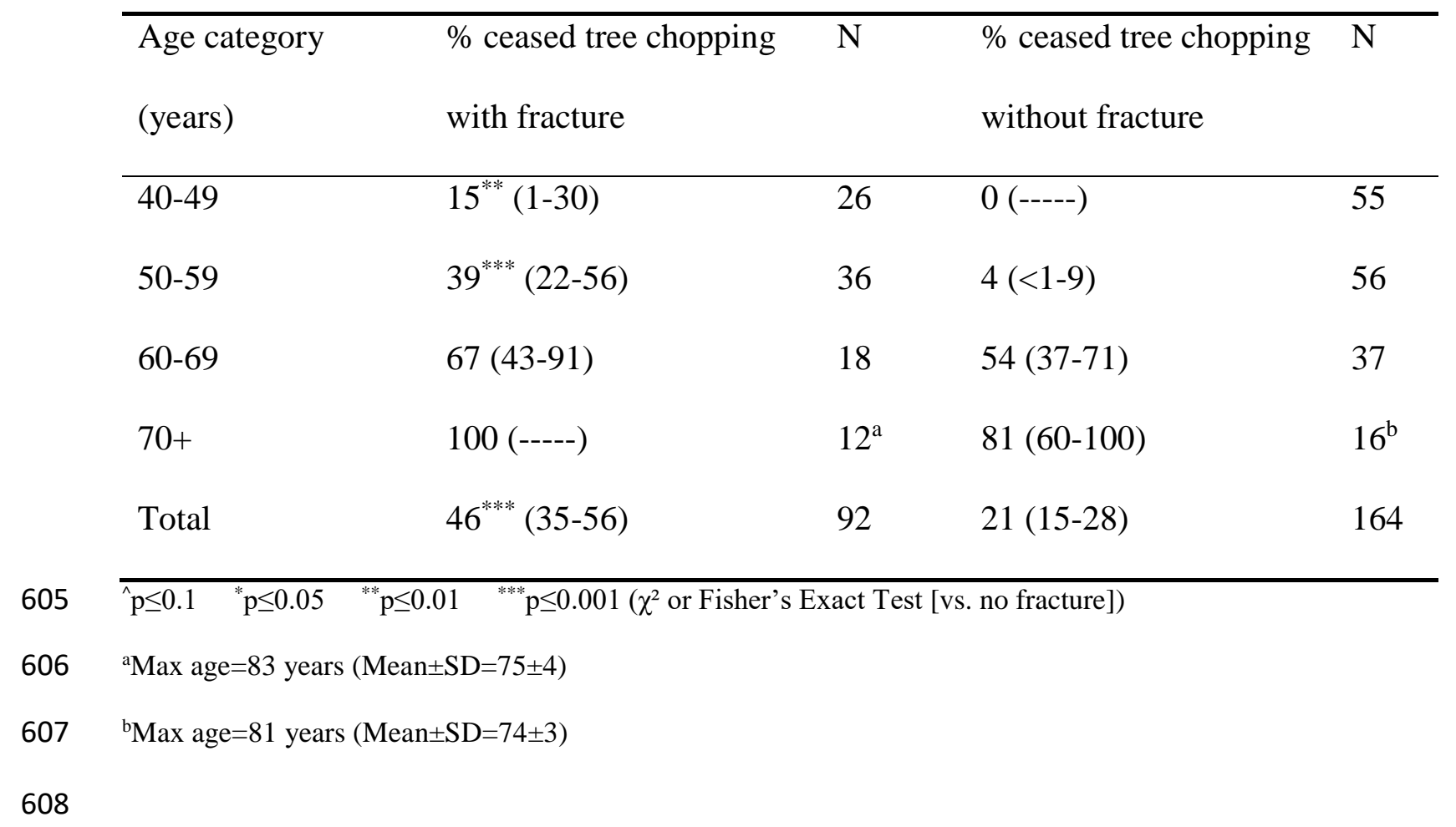

3.4. Tree chopping cessation is associated with thoracic vertebral body fracture but not lower $B M D$

Forty-six percent of men with fracture ceased chopping trees, compared to $21 \%$ with no fracture (Table 2). After adjusting for age, odds of tree chopping cessation are 6.9 times greater (95\% CI: 3.1-16.6, p<0.001, FDR q<0.001, n=256) for men with vs. without fracture (Appendix 1-table 6: Model 1). The association between odds of tree chopping cessation and fracture weakens slightly (adjusted $\mathrm{OR}_{\text {Fracture }}=6.8$ ) after also including thoracic vertebral body BMD as a covariate, which is not associated with tree chopping cessation (adjusted $\mathrm{OR}_{\mathrm{BMD} \text { per } \mathrm{SD}}=0.75,95 \%$ CI: 0.47-1.16, p=0.204, FDR q=0.306, Appendix 1-table 6: Model 2).

Table 2. Percentage of men (95\% CI) who completely ceased tree chopping by age and thoracic vertebral body fracture status. 
medRxiv preprint doi: https://doi.org/10.1101/2020.09.10.20191916; this version posted November 23, 2020. The copyright holder for this preprint (which was not certified by peer review) is the author/funder, who has granted medRxiv a license to display the preprint in perpetuity.

It is made available under a CC-BY-NC-ND 4.0 International license .

609

610

611

612

613

614

615

616

617

618

619

620

621

622

623

624

625

626

627

628

629

630

2

3.5. Weaving cessation is not associated with thoracic vertebral body fracture but is associated, albeit weakly, with lower BMD

Twenty percent of women with fracture ceased weaving, compared to $13 \%$ with no fracture (Table 3). After adjusting for age, odds of weaving cessation are not significantly associated with fracture (adjusted $\mathrm{OR}_{\text {Fracture }}=2.2,95 \%$ CI: 0.8-6.4, p=0.129, FDR q=0.172, $\mathrm{n}=237$, Appendix 1-table 7: Model 1). Weaving is the only task examined for which fracture is not associated with compromised participation. Adding BMD as a covariate further weakens the association between fracture and weaving cessation (adjusted $\mathrm{OR}_{\text {Fracture }}=1.8$; adjusted $\mathrm{OR}_{\mathrm{BMD} \text { per }}$ $\mathrm{SD}=0.51,95 \%$ CI: 0.23-1.05, p=0.079, FDR q=0.158, Appendix 1-table 7: Model 2). Regardless of fracture status or BMD, all women who stopped weaving reported experiencing problems in all bodily regions (i.e. hip, back and hands) mentioned by the physician during medical exams, and nearly all of these women also reported visual impairment (Appendix 1-table 8). 
631 Table 3. Percentage of women (95\% CI) who completely ceased weaving by age and thoracic 632 vertebral body fracture status.

\begin{tabular}{lllll}
\hline $\begin{array}{l}\text { Age category } \\
\text { (years) }\end{array}$ & $\begin{array}{l}\text { \% ceased weaving with } \\
\text { fracture }\end{array}$ & $\mathrm{N}$ & $\begin{array}{l}\text { \% ceased weaving without } \\
\text { fracture }\end{array}$ & $\mathrm{N}$ \\
\hline $40-49$ & $0(----)$ & 11 & $0(----)$ & 72 \\
$50-59$ & 22 & $5(<1-11)$ & 60 \\
$60-69$ & $14(<1-29)$ & 9 & $24(10-39)$ & 37 \\
$70+$ & $33(<1-72)$ & $4^{\mathrm{a}}$ & $55(32-77)$ & $22^{\mathrm{b}}$ \\
Total & $75(<1-100)$ & 46 & $13(8-17)$ & 191 \\
\hline
\end{tabular}

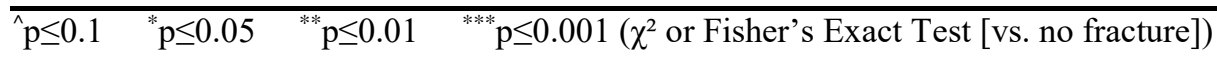

${ }^{b}$ Max age $=91$ years $($ Mean $\pm S D=77 \pm 6)$

3.6. Restricted day range is associated with thoracic vertebral body fracture and, albeit weakly, with lower BMD

Sixty-nine percent of adults with fracture are unable to walk a full day, compared to $38 \%$ 641 with no fracture (Table 4). After adjusting for age and sex, odds of inability to walk all day are 6428.2 times greater (95\% CI: 4.8-14.5, $\mathrm{p}<0.001$, FDR $\mathrm{q}<0.001, \mathrm{n}=493$ ) for adults with vs. without 643 fracture (Appendix 1-table 9: Model 1). The association between odds of inability to walk all day 644 and fracture weakens slightly (adjusted $\mathrm{OR}_{\text {Fracture }}=7.8$ ) after also including thoracic vertebral

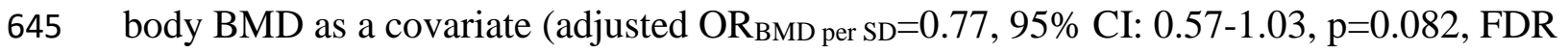
q=0.109, Appendix 1-table 9: Model 2). 
648 Table 4. Percentage of adults (95\% CI) who are unable to walk a full day by age and thoracic 649 vertebral body fracture status.

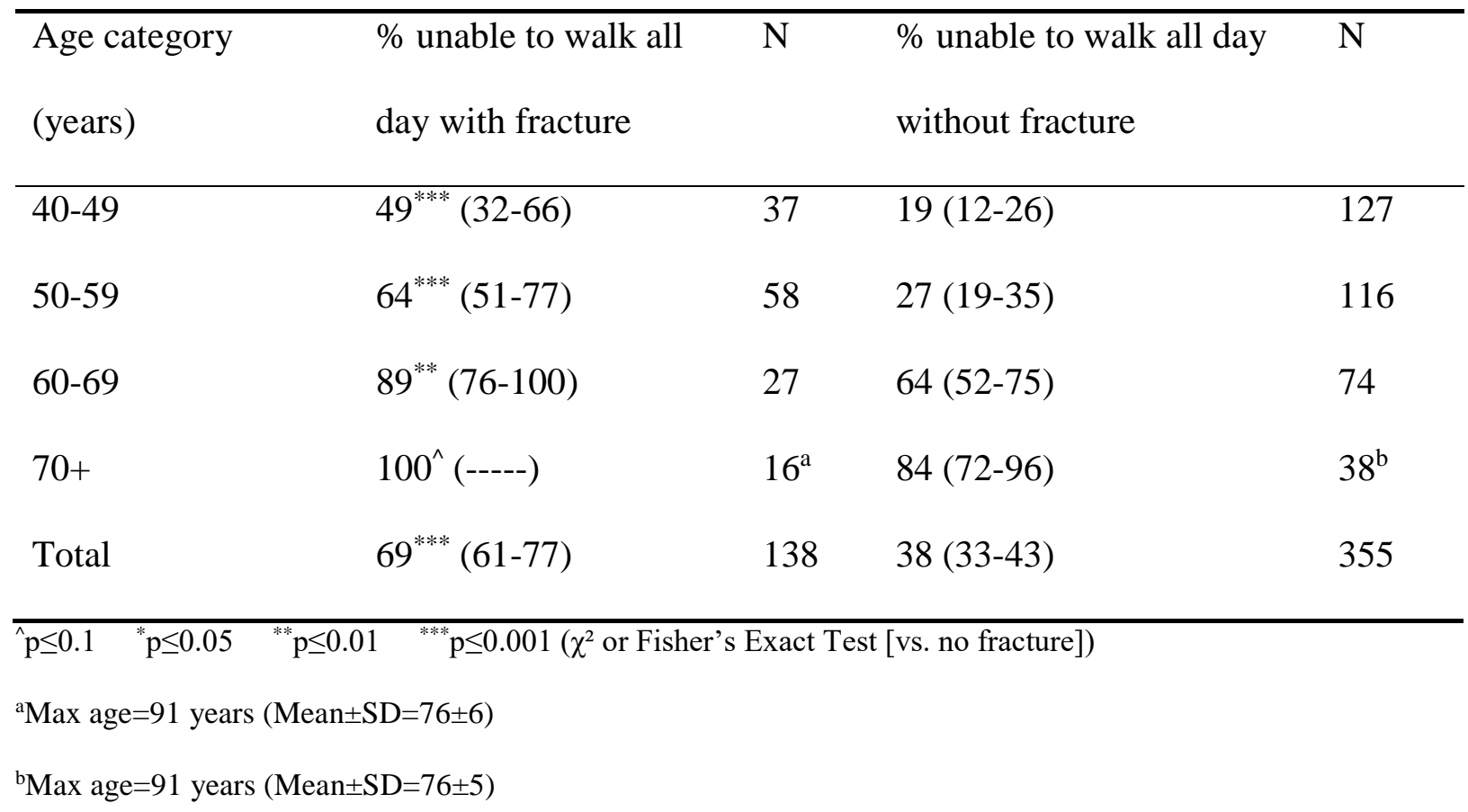

653

654

657 due to hip problems as a reason for hunting and tree chopping cessation (Appendix 1-tables 10-

658 11). This is noteworthy because among men who ceased hunting and tree chopping, men with

659 fracture are younger, on average, than men without fracture, and all else equal one expects

660 younger men to be less likely than older men to report hip problems (for men ceasing hunting:

661 mean age by fracture status=63 vs. 68; for men ceasing tree chopping: mean age=62 vs. 68).

662 Consistent with their younger age, men with fracture are less likely than men without fracture,

663 albeit not significantly, to report problems with endurance (i.e. feeling weak, tiring easily) or

664 sensory processing (i.e. auditory, visual) as reasons for hunting cessation (Appendix 1-table 10). 
665 It is thus less likely that men with fractures are in poorer condition more generally, and more 666 likely that fractures contributed to the mobility complaints that led men to stop hunting and tree

667 chopping. As with hunting and tree chopping, among adults who are unable to walk all day,

668 those with fracture are younger than those without fracture ${ }^{7}$ (mean age $=59$ vs. 62).

669

After adjusting for age and fat-free mass, men who are no longer able to hunt, chop trees,

670 and walk all day do not differ in their BMD vs. men who still hunt (95\% CI: $-18.1-4.4 \mathrm{mg} / \mathrm{cm}^{3}$ ),

671 chop trees (95\% CI: $\left.-15.0-7.1 \mathrm{mg} / \mathrm{cm}^{3}\right)$ and can walk all day ${ }^{8}\left(95 \% \mathrm{CI}:-10.2-7.9 \mathrm{mg} / \mathrm{cm}^{3}\right)$.

672 This suggests that men who cease these activities do not experience greater risk of overall

673 skeletal fragility. Lastly, if hunting or tree chopping cessation preceded fracture (e.g. because

674 reduced meat consumption weakened bone structural integrity, or because muscle degeneration

675 from task cessation reduced bone loading and structural integrity), then one might expect

676 anthropometric status to mediate the association between hunting or tree chopping cessation and

677 fracture. Yet these associations strengthen after adjusting for anthropometrics (i.e. weight, fat-

678 free mass and fat mass). Anthropometric status also does not mediate the association between

679 inability to walk all day and fracture. Together, these results provide suggestive evidence that

680 fracture preceded task cessation, rather than the reverse.

681

\section{Discussion}

\footnotetext{
${ }^{7}$ There are no differences by fracture status in self-reported reasons for inability to walk all day (see Appendix 1table 12).

${ }^{8}$ For women, inability to walk all day is associated with reduced BMD (95\% CI: $-25.3--6.1 \mathrm{mg} / \mathrm{cm}^{3}$ ) after adjusting for age and fat-free mass.
} 
medRxiv preprint doi: https://doi.org/10.1101/2020.09.10.20191916; this version posted November 23, 2020. The copyright holder for this preprint (which was not certified by peer review) is the author/funder, who has granted medRxiv a license to display the preprint in perpetuity.

It is made available under a CC-BY-NC-ND 4.0 International license .

We find among adult Tsimane forager-horticulturalists that compromised bone strength -as indicated by thoracic vertebral body fracture and lower thoracic vertebral body BMD -- is associated with diminished subsistence involvement. Compromised bone strength is associated with diminished participation in diverse habitual subsistence tasks, particularly those requiring high levels of strength or endurance (i.e. hunting, tree chopping, walking long distances). In contrast, participation in less physically demanding but skill-intensive tasks (i.e. tool manufacture/repair) is only modestly associated with bone strength. Since strength and endurance are required to exploit the suite of resources upon which omnivorous hominins rely, functional disability may hinder resource production in costly ways for a comparatively longliving, extractive foraging primate. This inference is supported by prior studies in other contemporary small-scale populations that highlight impairments of shorter duration (e.g. acute infection, laceration, animal bite) as constraints on productivity (Bailey 1991; Sugiyama and Chacon 2000; Sugiyama 2004). As most activities of daily living generate loads on human vertebrae (Myers and Wilson 1997; Rohlmann et al. 2001; Stewart and Hall 2006), and since for many activities the greatest compressive loads along the spine are in the thoracolumbar region (Bruno et al. 2017), thoracic vertebral body fracture in particular may be debilitating for an obligate biped even after behavioral modifications that minimize its burden.

Ample bioarchaeological evidence of partially or fully healed fractures (e.g. (Lovejoy and Heiple 1981; Pfeiffer 2012)), usually from excessive trauma, and developmental abnormalities (Cowgill et al. 2015; Trinkaus 2018) suggest in past populations longer-term survival with varying levels of disability. Fragility fractures resulting from reduced bone strength are relatively rare in bioarchaeological studies (Agarwal 2008; Agarwal and Grynpas 1996), even among the elderly, leading some to conclude that osteoporosis was rare or absent in past 
706

707

708

709

710

711

712

713

714

715

716

717

718

719

720

721

722

723

724

725

726

727

728

populations (but see (Curate et al. 2010; Dequeker et al. 1997)). This and the fact that agespecific osteoporotic fracture incidence rates appear to be increasing over time in Western populations (Cooper et al. 2011) lends support to the notion that osteoporosis is a "disease of modernity” (cf. (Kralick and Zemel 2020; Lieberman 2013)). However, few if any bioarchaeologists systematically study thoracic vertebral compression fractures, and a paucity of observed fragility fractures in the archaeological record is partly due to biased preservation of skeletal remains. Accelerated bone loss with age appears to be a basic feature of human aging in past and present populations (Aspray et al. 1996; Kneissel et al. 1997; Mays et al. 1998; Mays 1996; Wallace et al. 2014) and has also been documented among free-ranging chimpanzees (Gunji et al. 2003; Morbeck et al. 2002; Sumner et al. 1989). It would thus be premature to conclude that fragility fractures were rare or of minimal consequence throughout human evolution.

We find suggestive evidence that Tsimane fracture precedes subsistence task cessation, rather than the reverse (section 3.7). But there are several possible explanations for the empirical associations reported in this paper, as shown in Figure 6, and given the study design we cannot definitively parse among them. Associations between reduced thoracic vertebral body BMD and task cessation may reflect effects on functional ability of other properties of senescence that were not examined here. The present study does not consider diverse mechanisms (e.g. spinal osteoarthritis, restricted range of motion for a given anatomical region) and future research is needed to establish causal relationships between somatic condition, functional ability and productivity. A candidate model that is only partially evaluated in this paper (Figure 6) proposes that senescence induces anatomical and sensory declines - including loss of strength in muscles, bones and connective tissues - which jointly increase risk of fracture, body pain or discomfort, 
729 and functional disability. Senescence-induced declines can also induce pain and disability in the

730 absence of fracture or reduced BMD too (e.g. from osteoarthritis). The magnitude and pace of

731 anatomical and sensory decline may be influenced not just by senescence but also by habitual

732 participation in strenuous subsistence labor (i.e. “mechanical wear and tear”), which can directly

733 cause fracture (e.g. via excessive mechanical stress) and body pain. The manifestation of pain

734 and functional disability following fracture appears to be quite variable both across individuals

735 and within individuals over time (e.g. (Begerow et al. 1999; Nevitt et al. 1998; O'Neill et al.

736 2004; Suzuki et al. 2008) and samples are usually not representative of the population since

737 many fractures remain unobserved. Back pain in particular can arise directly from vertebral

738 fracture or indirectly from consequences of spinal deformity or degenerative changes involving

739 paravertebral muscles, intervertebral discs, associated ligaments and facet joints. Fractures in

740 particular can entail longer-term productivity constraints as they provoke systemic bone losses,

741 incomplete recovery of bone quality (especially for older adults), increased risk of future

742 fractures and longer-term disability (Osipov et al. 2018). Future research is needed to test the

743 empirical adequacy of the hypothesized, sometimes bidirectional relationships shown in Figure

744 6. It is also possible that our results reflect influences of earlier life factors (e.g. activity levels,

745 peak bone mass, economic productivity) that we do not examine in the present study. 
medRxiv preprint doi: https://doi.org/10.1101/2020.09.10.20191916; this version posted November 23, 2020. The copyright holder for this preprint (which was not certified by peer review) is the author/funder, who has granted medRxiv a license to display the preprint in perpetuity.

It is made available under a CC-BY-NC-ND 4.0 International license .

751 Figure 6. A conceptual model linking somatic condition to economic productivity during aging 752 in small-scale subsistence societies. Variables in red are a focus of the present study.

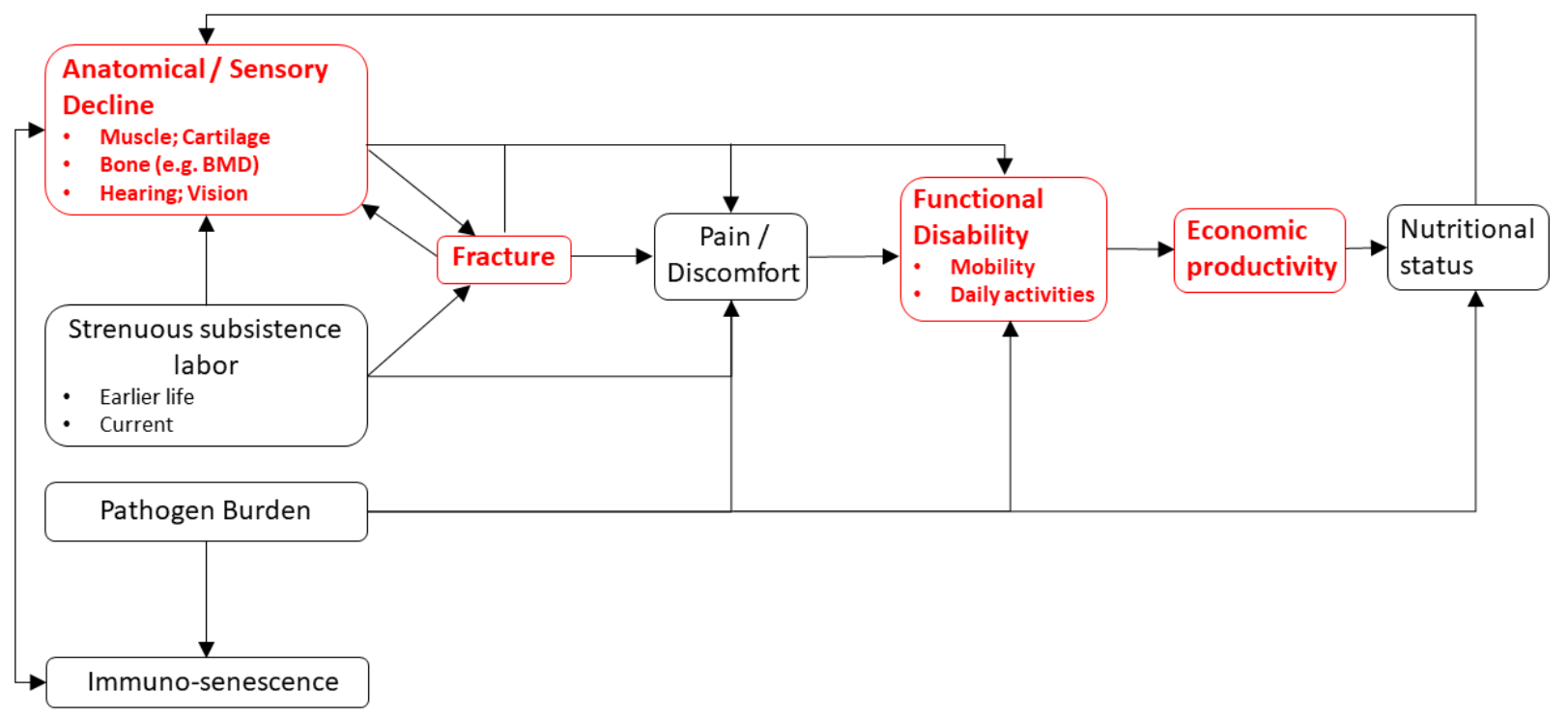

Tsimane thoracic vertebral fractures appear to result from both trauma and senescence

757 (Stieglitz et al. 2019) and are not just prevalent among the oldest adults (Figures 2-3). Tsimane association between BMD and fracture risk (Stieglitz et al. 2019), and our anecdotal observations of high levels of mechanical stress on men's vertebrae from frequent heavy load carrying (e.g. of animal carcasses, and timber for constructing houses). This of course does not preclude a

765 contributing role of compromised bone strength in precipitating men's fracture. Likewise, for 766 women, trauma may also precipitate fracture; some of the greatest compressive vertebral loads 
767 occur when weights are carried in front of the body (Bruno et al. 2017; Rohlmann et al. 2001),

768 which is how Tsimane women routinely carry infants and toddlers. High reproductive effort (i.e.

769 early onset of reproduction, on-demand breastfeeding, short interbirth intervals, and high parity)

770 is associated with reduced bone strength for Tsimane women (Stieglitz et al. 2015a; Stieglitz et

771 al. 2019) and may thus constrain the ability of bone tissue to respond to mechanical loading from

772 a physically active lifestyle. Interpersonal violence likely does not precipitate much fracture

773 among men because such violence is relatively rare and generally does not result in severe

774 injuries when it does occur. However, intimate partner violence against women is prevalent

775 (Stieglitz et al. 2018), particularly among younger women, and may precipitate traumatic

776 fracture at diverse skeletal sites.

777 To more precisely identify the economic cost of disability, we estimated age-specific

778 energetic deficits from hunting cessation by men with compromised bone strength. An advantage

779 of our approach to estimating productivity loss is that it is not subject to recall inaccuracy or

780 subjectivity regarding the meaning of foregone production. Energetic deficits are substantial,

781 averaging from ages 40-74 years 261 lost hunting kcals/day for men with vs. without fracture

782 (Figure 4, Appendix 1-table 4). Average production deficits are even greater for men with both

783 fracture and lower BMD (vs. men without fracture and higher BMD): 397 lost hunting kcals/day,

784 equivalent to $15 \%$ of the mean daily per-capita energy intake, and $44 \%$ of the mean intake from

785 protein and fat (Kraft et al. 2018) (Figure 5, Appendix 1-table 5). By crude comparison, adults in

786 Western industrialized settings with musculoskeletal problems show productivity losses of 10-

787 15\% for frequent computer users across various industries (Hagberg et al. 2002) and up to 28\%

788 for construction workers with more physically demanding jobs (Meerding et al. 2005). For

789 osteoporotic adults aged 50+ years in the Netherlands, the cost of clinical spine fracture in terms 
790 of work absenteeism exceeds $25 \%$ of the mean annual income (Eekman et al. 2014). Tsimane

791 age-specific energetic deficits peak in the early 60s (Figures 4-5, Appendix 1-tables 4-5), which

792 is near the age at which adults achieve peak numbers of dependent offspring and grand offspring

793 (Gurven and Kaplan 2007). The magnitude of these disability costs and their timing in the life

794 cycle may thus pose for Tsimane significant challenges to meeting adult survival needs and/or

795 providing assistance (material or other) to descendant kin. These challenges should vary in

796 severity across populations depending on fertility schedules and dependency loads. Our results

797 suggest that the scope of behavioral responses to compensate for productivity loss are limited to

798 activities with lower strength and endurance requirements (sections 3.4-3.6). Given the ubiquity

799 across subsistence populations of the sexual division of labor, with men typically focusing on

800 high strength tasks, aging women may maintain peak or near-peak subsistence involvement with

801 relatively minimal disability-related productivity losses, despite increasing frailty. Relatedly, in

802 industrialized populations there is some evidence from population-based cohorts that severe

803 thoracolumbar vertebral deformity is more strongly associated with functional impairments for

804 men than women (Burger et al. 1997), perhaps because men load their spines more heavily.

Faced with protein and fat deficits from hunting cessation, one might expect adults with compromised bone strength to increase time spent in other, less physically demanding food

807 acquisition tasks that reliably yield substitutable macronutrients. Fishing is the other major 808 source of protein and fat in small-scale Amazonian subsistence populations, most of whom 809 acquire protein more efficiently from animal- rather than plant-based foods (Hames 1989). Prior 810 behavioral studies of other contemporary Amazonian populations (Gurven and Kaplan 2006)

811 indicate a shift with age in men’s time allocation away from hunting and instead towards fishing;

812 for both sexes time spent fishing increases monotonically throughout adulthood. Fishing is also 
medRxiv preprint doi: https://doi.org/10.1101/2020.09.10.20191916; this version posted November 23, 2020. The copyright holder for this preprint (which was not certified by peer review) is the author/funder, who has granted medRxiv a license to display the preprint in perpetuity.

It is made available under a CC-BY-NC-ND 4.0 International license .

813 an important source of protein and fat for Tsimane (Gurven et al. 2013; Hooper 2011). To wholly

814 offset their own hunting productivity losses, men with fracture and lower BMD would have to

815 considerably increase their time spent fishing (section 3.3). A perceived need by adults to offset

816 their own current and/or future energetic deficits (Figures 4-5) could influence residential

817 decisions by increasing the value of maintaining proximity to fishing locations (e.g. rivers,

818 lakes), particularly during periods of greater fishing efficiency (e.g. dry season). Disability-

819 related production deficits could influence various economic decisions (e.g. by influencing

820 decisions on where to forage on a given day, or where to farm). Minimizing travel costs during

821 food acquisition may be important in light of restricted day ranges among adults with

822 compromised bone strength (section 3.6). These economic decisions also depend on local

823 demographics and social networks, as productivity losses can be mitigated with the availability

824 of substitute workers. If, for instance, able-bodied adults within the multi-generational sharing

825 unit can substitute for impaired adults in hunting and meat sharing, then impaired adults may

826 take fewer risks to acquire protein and fat compared to those without buffered networks.

827

Our estimates of the ways in which Tsimane with compromised bone strength may

828 compensate for hunting productivity loss are crude for several reasons. They do not, for example,

829 consider the possibility of adults being provisioned by others, or pursuing other means of protein

830 and fat acquisition beyond fishing. Tsimane can pursue other low-intensity subsistence tasks

831 (e.g. harvesting cultigens), thereby offering additional opportunities for adults to produce and

832 transfer resources outside of a strict hunting and gathering economy. Our crude estimates

833 nevertheless imply that productivity losses entail behavioral modifications and might affect

834 social organization more broadly. The multi-generational production and sharing units that

835 structure human sociality (Bird et al. 2019; Isaac 1978; Migliano et al. 2017; Washburn and 
medRxiv preprint doi: https://doi.org/10.1101/2020.09.10.20191916; this version posted November 23, 2020. The copyright holder for this preprint (which was not certified by peer review) is the author/funder, who has granted medRxiv a license to display the preprint in perpetuity.

It is made available under a CC-BY-NC-ND 4.0 International license .

836

837

838

839

840

841

842

843

844

845

846

847

848

849

850

851

852

853

854

855

856

857

858

Lancaster 1968b) incorporate divisions of labor whereby impaired adults can still make valuable contributions beyond food acquisition (e.g. through conflict mediation, pedagogy, leadership).

Older adults play an important fitness-enhancing role not just by providing caloric surpluses and transfers, but also by providing childcare, skills and knowledge, and other resources. Tsimane cognitive function is generally well preserved throughout adulthood among both schooled and non-schooled adults (Gurven et al. 2017), consistent with a late-life service niche emphasizing vertical information transmission of accumulated wisdom, experience and judgment. Aging Tsimane adults, despite their declining physical abilities, are regularly consulted and respected for their knowledge of the natural and spiritual world (e.g. profitable hunting locations, proper ethics), family lineage histories and past events, healing sick group members, making household crafts, and traditional stories and music (Schniter et al. 2015; Schniter et al. 2018). Aging adults accommodate their changing roles within the family and society and gradually compensate for their increasing frailty by providing valuable expertise across diverse skill- and knowledgeintensive domains that facilitate achieving the childrearing and subsistence goals of the residential group (cf. (Levitin 2020)).

The extent to which our results generalize across time and space depends on various considerations including age profiles of production, rates of mortality and senescence, and subsistence ecology (e.g. reliance on hunted versus other foods). Fertility patterns are not explicitly considered in the present study, but they can also influence both somatic condition, particularly for women (Jasienska 2020; Ryan et al. 2018; Stieglitz et al. 2015a; Stieglitz et al. 2019; Ziomkiewicz et al. 2016), and economic productivity (Hooper et al. 2015; Kramer 2005).

Extensive longevity may be a novel life history feature of modern $H$. sapiens that was absent among prior hominin species; extant hunter-gatherers with relatively minimal acculturation 
medRxiv preprint doi: https://doi.org/10.1101/2020.09.10.20191916; this version posted November 23, 2020. The copyright holder for this preprint (which was not certified by peer review) is the author/funder, who has granted medRxiv a license to display the preprint in perpetuity.

It is made available under a CC-BY-NC-ND 4.0 International license .

859 exhibit a modal adult lifespan of 68-78 years (Gurven and Kaplan 2007). It is thus possible that

860 our estimates of disability-related productivity loss are more relevant for understanding lifeways

861 of past hominin populations with more similar life histories as modern $H$. sapiens and perhaps

862 some archaic humans (e.g. H. heidelbergensis), but less applicable to Lower Paleolithic and

863 earlier hominins with shorter adult lifespans. Whether lifespans were too short for some fossil

864 hominins to expect significant post-reproductive longevity is vigorously debated (see (Gurven

865 and Kaplan 2007; Hawkes 2003; Hill et al. 2007) and references therein). One study using

866 dental-wear seriation and relative macro-age categories (ratio of old to young) demonstrated an

867 increase in the relative presence of older adults from Australopithecines to early Homo and Early

868 Upper Paleolithic humans ((Caspari and Lee 2004); but see (Hawkes and O'Connell 2005;

869 Minichillo 2005)). Re-estimation of several paleo-mortality curves based on hazard analysis and

870 maximum likelihood methods shows a life course pattern more similar to that of modern human

871 hunter-gatherers than previous methods (Konigsberg and Herrmann 2006). Development of

872 reliable paleo-demographic reconstructions of hominin life histories (e.g. see (DeWitte and

873 Stojanowski 2015) are critical for determining generalizability of the results presented here.

874 Moreover, disability-related productivity losses could change based on variation in ancestral

875 hominin vertebral morphology that can affect interpretation of fracture results using Genant's

876 semi-quantitative technique (cf. (Trinkaus 2018)).

877

878 4.1. Conclusion

879

In comparative cross-species perspective, modern human life histories are characterized

880 by delayed peak foraging efficiency (e.g. (Kaplan 1994; Kaplan 1997; Koster et al. 2020; Walker

881 et al. 2002)), complex cooperative strategies to produce and rear altricial, slow-growing 
882 offspring (e.g. (Hawkes 2003; Kaplan and Hill 1985; Richerson and Boyd 2008; Wood and

883 Marlowe 2013)), low adult mortality rate (e.g. (Hill et al. 2001; Wood et al. 2017)) and long

884 post-reproductive lifespan (e.g. (Gurven and Kaplan 2007; Hawkes et al. 1998; Kaplan et al.

885 2010)). Energetic transfers from older to younger generations help mitigate risk of production

886 deficits in a skill- and strength-based extractive foraging niche (Gurven et al. 2012; Hawkes et al.

887 1998; Hooper et al. 2015; Kaplan et al. 2010). In this paper we considered energetic deficits

888 associated with compromised bone strength, which may have constrained economic productivity

889 and resource transfers for extended periods throughout much of human history (Bailey 1991;

890 Gurven et al. 2000; Lambert and Welker 2017; Sugiyama 2004). While we provide suggestive

891 evidence of a causal relationship between bone properties and functional disability, changes in

892 bone strength may reflect a combination of earlier life factors (e.g. trauma, activity levels), or

893 other senescent processes.

Perhaps not surprisingly, Ache hunters cite fear of disability as an important reason why 2009). It has been proposed that individuals may have survived periods of prolonged disability

897 only via costly provisioning and care by others (Gurven et al. 2000; Sugiyama and Chacon

898 2000), although the extent to which others adjust their activity budgets, food production and

899 sharing to compensate for disability-related productivity loss is beyond the scope of the present 900 study. Our findings nevertheless suggest that disability may be economically costly.

Vertebral deformities are observed in diverse hominin skeletal samples yet the social and

902 behavioral implications of these deformities remain obscure. In the absence of direct evidence of

903 disability-related productivity loss in the fossil record, bone properties may represent a potential

904 proxy for inferring behavioral consequences of skeletal deformity in prior hominin populations. 
905 Quantification of microstructural variation in the appendicular and axial skeleton of fossil

906 hominins may provide evidence for inferring foraging behavior, as detailed in the present study.

907 While our ability to make inferences about the past using data collected in contemporary

908 populations is limited, studies of contemporary small-scale subsistence populations like the

909 Tsimane can offer a unique opportunity to examine potential consequences of skeletal deformity

910 in a population-representative adult sample. The present study provides a framework for

911 interpreting morphological signals identified in the fossil record; while this study is narrowly

912 focused on specific morphological features, and while it overlooks important subsistence tasks

913 performed by women, it can nonetheless be an exemplar for future ethno-archaeological inquiry

914 into potential economic and social consequences of disability in past human populations.

915

916 Competing interests

917 The authors declare no competing interests.

919 References

920 Agarwal S. 2008. Light and Broken Bones: Examining and Interpreting Bone Loss and 246(4):423-432.

925 Aiello LC, and Wheeler P. 1995. The Expensive-Tissue Hypothesis: The Brain and the Digestive System in Human and Primate Evolution. Current Anthropology 36(2):199-221. 
927

928

929

930

931

932

933

934

935

936

937

938

939

940

941

942

943

944

945

946

947

948

949

Antón SC, Potts R, and Aiello LC. 2014. Evolution of early <em>Homo</em>: An integrated biological perspective. Science 345(6192):1236828.

Aspray TJ, Prentice A, Cole TJ, Sawo Y, Reeve J, and Francis RM. 1996. Low bone mineral content is common but osteoporotic fractures are rare in elderly rural Gambian women. J Bone Miner Res 11(7):1019-1025.

Bailey R. 1991. The Behavioral Ecology of Efe Pygmy Men in the Ituri Forest, Zaire. Ann Arbor: Museum of Anthropology, University of Michigan.

Balikci A. 1970. The Netsilik Eskimo. New York: Natural History Press.

Begerow B, Pfeifer M, Pospeschill M, Scholz M, Schlotthauer T, Lazarescu A, Pollaehne W, and Minne HW. 1999. Time since vertebral fracture: an important variable concerning quality of life in patients with postmenopausal osteoporosis. Osteoporos Int 10(1):26-33.

Bird DW, Bird RB, Codding BF, and Zeanah DW. 2019. Variability in the organization and size of hunter-gatherer groups: Foragers do not live in small-scale societies. Journal of Human Evolution 131:96-108.

Bird RB, Smith E, and Bird DW. 2001. The hunting handicap: costly signaling in human foraging strategies. Behavioral Ecology and Sociobiology 50(1):9-19.

Bonmatí A, Gómez-Olivencia A, Arsuaga J-L, Carretero JM, Gracia A, Martínez I, Lorenzo C, Bérmudez de Castro JM, and Carbonell E. 2010. Middle Pleistocene lower back and pelvis from an aged human individual from the Sima de los Huesos site, Spain. Proceedings of the National Academy of Sciences 107(43):18386-18391.

Braun DR, Plummer T, Ditchfield P, Ferraro JV, Maina D, Bishop LC, and Potts R. 2008. Oldowan behavior and raw material transport: perspectives from the Kanjera Formation. Journal of Archaeological Science 35(8):2329-2345. 
medRxiv preprint doi: https://doi.org/10.1101/2020.09.10.20191916; this version posted November 23, 2020. The copyright holder for this preprint (which was not certified by peer review) is the author/funder, who has granted medRxiv a license to display the preprint in perpetuity.

It is made available under a CC-BY-NC-ND 4.0 International license .

950

951

952

953

954

955

956

957

958

959

960

961

962

963

964

965

966

967

968

969

970

971

Bruno AG, Burkhart K, Allaire B, Anderson DE, and Bouxsein ML. 2017. Spinal Loading

Patterns From Biomechanical Modeling Explain the High Incidence of Vertebral

Fractures in the Thoracolumbar Region. J Bone Miner Res 32(6):1282-1290.

Budoff MJ, Hamirani YS, Gao YL, Ismaeel H, Flores FR, Child J, Carson S, Nee JN, and Mao

S. 2010. Measurement of thoracic bone mineral density with quantitative CT. Radiology 257(2):434-440.

Budoff MJ, Khairallah W, Li D, Gao YL, Ismaeel H, Flores F, Child J, Carson S, and Mao SS. 2012. Trabecular bone mineral density measurement using thoracic and lumbar quantitative computed tomography. Academic radiology 19(2):179-183.

Budoff MJ, Malpeso JM, Zeb I, Gao YL, Li D, Choi TY, Dailing CA, and Mao SS. 2013. Measurement of phantomless thoracic bone mineral density on coronary artery calcium CT scans acquired with various CT scanner models. Radiology 267(3):830-836.

Burger H, Van Daele PLA, Grashuis K, Hofman A, Grobbee DE, Schütte HE, Birkenhäger JC, and Pols HAP. 1997. Vertebral Deformities and Functional Impairment in Men and Women. Journal of Bone and Mineral Research 12(1):152-157.

Caspari R, and Lee S-H. 2004. Older age becomes common late in human evolution. Proceedings of the National Academy of Sciences of the United States of America 101(30):10895-10900.

Chapman FH. 1972. Vertebral osteophytosis in prehistoric populations of central and southern Mexico. Am J Phys Anthropol 36(1):31-38.

Cook DC, Buikstra JE, DeRousseau CJ, and Johanson DC. 1983. Vertebral pathology in the afar australopithecines. Am J Phys Anthropol 60(1):83-101. 
medRxiv preprint doi: https://doi.org/10.1101/2020.09.10.20191916; this version posted November 23, 2020. The copyright holder for this preprint (which was not certified by peer review) is the author/funder, who has granted medRxiv a license to display the preprint in perpetuity.

It is made available under a CC-BY-NC-ND 4.0 International license .

972 Cooper C, Cole ZA, Holroyd CR, Earl SC, Harvey NC, Dennison EM, Melton LJ, Cummings

973 SR, and Kanis JA. 2011. Secular trends in the incidence of hip and other osteoporotic

974 fractures. Osteoporos Int 22(5):1277-1288.

975 Cotter MM, Loomis DA, Simpson SW, Latimer B, and Hernandez CJ. 2011. Human Evolution 976 and Osteoporosis-Related Spinal Fractures. PLoS ONE 6(10):e26658.

977 Cowgill LW, Mednikova MB, Buzhilova AP, and Trinkaus E. 2015. The Sunghir 3 Upper 978 Paleolithic Juvenile: Pathology versus Persistence in the Paleolithic. International Journal of Osteoarchaeology 25(2):176-187.

980 Curate F, Lopes C, and Cunha E. 2010. A 14th-17th century osteoporotic hip fracture from the Santa Clara-a-Velha Convent in Coimbra (Portugal). International Journal of Osteoarchaeology 20(5):591-596.

983

Dequeker J, Ortner DJ, Stix AI, Cheng XG, Brys P, and Boonen S. 1997. Hip fracture and osteoporosis in a XIIth Dynasty female skeleton from Lisht, upper Egypt. J Bone Miner Res 12(6):881-888. Perspectives, Future Directions. Journal of Archaeological Research 23(4):397-450. Indirect costs account for half of the total costs of an osteoporotic fracture: a prospective evaluation. Osteoporos Int 25(1):195-204. 
medRxiv preprint doi: https://doi.org/10.1101/2020.09.10.20191916; this version posted November 23, 2020. The copyright holder for this preprint (which was not certified by peer review) is the author/funder, who has granted medRxiv a license to display the preprint in perpetuity.

It is made available under a CC-BY-NC-ND 4.0 International license .

993

994

995

996

997

998

999

1000

1001

1002

1003

1004

1005

1006

1007

1008

1009

1010

1011

1012

1013

1014

Finch CE. 2010. Evolution of the human lifespan and diseases of aging: Roles of infection, inflammation, and nutrition. Proceedings of the National Academy of Sciences 107(suppl 1):1718-1724.

Foldes AJ, Moscovici A, Popovtzer MM, Mogle P, Urman D, and Zias J. 1995. Extreme osteoporosis in a sixth century skeleton from the Negev desert. International Journal of Osteoarchaeology 5(2):157-162.

Francis RM, Aspray TJ, Hide G, Sutcliffe AM, and Wilkinson P. 2008. Back pain in osteoporotic vertebral fractures. Osteoporos Int 19(7):895-903.

Genant HK, Wu CY, van Kuijk C, and Nevitt MC. 1993. Vertebral fracture assessment using a semiquantitative technique. Journal of Bone and Mineral Research 8(9):1137-1148.

Gresky J, Wagner M, Schmidt-Schultz TH, Schwarz L, Wu X, Aisha A, Tarasov PE, and Schultz M. 2016. 'You must keep going' - Musculoskeletal system stress indicators of prehistoric mobile pastoralists in Western China. Quaternary International 405:186-199.

Gunji H, Hosaka K, Huffman MA, Kawanaka K, Matsumoto-Oda A, Hamada Y, and Nishida T. 2003. Extraordinarily low bone mineral density in an old female chimpanzee (Pan troglodytes schweinfurthii) from the Mahale Mountains National Park. Primates 44(2):145-149.

Gurven M, Allen-Arave W, Hill K, and Hurtado M. 2000. “It's a Wonderful Life”: signaling generosity among the Ache of Paraguay. Evolution and Human Behavior 21(4):263-282.

Gurven M, Fuerstenberg E, Trumble B, Stieglitz J, Davis H, and Kaplan H. 2017. Cognitive performance across the life course among Bolivian forager-farmers with limited schooling. Developmental Psychology. 
medRxiv preprint doi: https://doi.org/10.1101/2020.09.10.20191916; this version posted November 23, 2020. The copyright holder for this preprint (which was not certified by peer review) is the author/funder, who has granted medRxiv a license to display the preprint in perpetuity.

It is made available under a CC-BY-NC-ND 4.0 International license .

1015 Gurven M, Jaeggi AV, Kaplan H, and Cummings D. 2013. Physical Activity and Modernization 1016 among Bolivian Amerindians. Plos One 8(1):e55679.

1017 Gurven M, and Kaplan H. 2006. Determinants of time allocation across the lifespan: A

1018

1019 theoretical model and an application to the Machiguenga and Piro of Peru. Human Nature

1020

Gurven M, and Kaplan H. 2007. Longevity Among Hunter-Gatherers: A Cross-Cultural

1021 Examination. Population and Development Review 33(2):321-365.

1022 Gurven M, Kaplan H, and Gutierrez M. 2006. How long does it take to become a proficient 1023 hunter? Implications for the evolution of extended development and long life span.

1024 Journal of Human Evolution 51:454 - 470.

1025

Gurven M, Kraft TS, Alami S, Adrian JC, Linares EC, Cummings D, Rodriguez DE, Hooper PL, 1026 Jaeggi AV, Gutierrez RQ et al. . 2020a. Rapidly declining body temperature in a tropical human population. Science Advances 6(44).

1028

Gurven M, Stieglitz J, Hooper PL, Gomes C, and Kaplan H. 2012. From the womb to the tomb: The role of transfers in shaping the evolved human life history. Experimental Gerontology 47:807-813. approach to marriage and the sexual division of labor. Human Nature 20(2):151-183.

1033 Gurven MD, Davison RJ, and Kraft TS. 2020b. The optimal timing of teaching and learning across the life course. Philosophical Transactions of the Royal Society B: Biological Sciences 375(1803):20190500. 
medRxiv preprint doi: https://doi.org/10.1101/2020.09.10.20191916; this version posted November 23, 2020. The copyright holder for this preprint (which was not certified by peer review) is the author/funder, who has granted medRxiv a license to display the preprint in perpetuity.

It is made available under a CC-BY-NC-ND 4.0 International license .

1036

1037

1038

1039

1040

1041

1042

1043

1044

1045

1046

1047

1048

1049

1050

1051

1052

1053

1054

1055

1056

1057

Hagberg M, Tornqvist EW, and Toomingas A. 2002. Self-reported reduced productivity due to musculoskeletal symptoms: associations with workplace and individual factors among white-collar computer users. Journal of occupational rehabilitation 12(3):151-162.

Hames R. 1989. Time, efficiency, and fitness in the Amazonian protein quest. Research in Economic Anthropology 11:43-85.

Hawkes K. 2003. Grandmothers and the evolution of human longevity. American Journal of Human Biology 15:380 - 400.

Hawkes K, O'Connell J, and Blurton Jones N. 2001. Hunting and nuclear families: Some lessons from the Hadza about men's work. Current Anthropology 42:681 - 709.

Hawkes K, O'Connell J, Blurton Jones N, Alvarez H, and Charnov E. 1998. Grandmothering, menopause, and the evolution of human life histories. Proceedings of the National Academy of Sciences 95:1336 - 1339.

Hawkes K, and O'Connell JF. 2005. How old is human longevity? J Hum Evol 49(5):650-653; discussion 654-659.

Hill K, Boesch C, Goodall J, Pusey A, Williams J, and Wrangham R. 2001. Mortality rates among wild chimpanzees. J Hum Evol 40(5):437-450.

Hill K, and Hurtado AM. 2009. Cooperative breeding in South American hunter-gatherers. Proceedings of the Royal Society B: Biological Sciences 276(1674):3863-3870.

Hill K, Hurtado AM, and Walker RS. 2007. High adult mortality among Hiwi hunter-gatherers: implications for human evolution. J Hum Evol 52(4):443-454.

Ho C, Kim R, Schaffler M, and Sartoris D. 1990. Accuracy of dual-energy radiographic absorptiometry of the lumbar spine: cadaver study. Radiology 176(1):171-173. 
medRxiv preprint doi: https://doi.org/10.1101/2020.09.10.20191916; this version posted November 23, 2020. The copyright holder for this preprint (which was not certified by peer review) is the author/funder, who has granted medRxiv a license to display the preprint in perpetuity.

It is made available under a CC-BY-NC-ND 4.0 International license .

1058

1059

1060

1061

1062

1063

1064

1065

1066

1067

1068

1069

1070

1071

1072

1073

1074

1075

1076

1077

1078

1079

1080

Hooper P. 2011. The structure of energy production and redistribution among Tsimane' foragerhorticulturalists. [Ph.D. dissertation]. Albuquerque: University of New Mexico.

Hooper P, Gurven M, and Kaplan H. 2014. Social Underpinnings of Human Biodemography. Advances in Biodemography: Cross-Species Comparisons of Social Environments and Social Behaviors, and their Effects on Health and Longevity. Washington, D.C.: National Academy Press.

Hooper PL, Gurven M, Winking J, and Kaplan HS. 2015. Inclusive fitness and differential productivity across the life course determine intergenerational transfers in a small-scale human society. Proceedings of the Royal Society of London B: Biological Sciences 282(1803):20142808.

Isaac G. 1978. The food-sharing behavior of protohuman hominids. Scientific American 238:90108.

Jasienska G. 2020. Costs of reproduction and ageing in the human female. Philosophical Transactions of the Royal Society B: Biological Sciences 375(1811):20190615.

Jurmain R. 2000. Degenerative joint disease in African great apes: an evolutionary perspective. J Hum Evol 39(2):185-203.

Kaplan H. 1994. Evolutionary and wealth flows theories of fertility: Empirical tests and new models. Population and Development Review 20:753 - 791.

Kaplan H. 1997. The evolution of the human life course. In: Wachter K, and Finch C, editors. Between Zeus and the Salmon: The Biodemography of Aging. Washington, D.C.: National Academy of Sciences. p 175 - 211.

Kaplan H, Gurven M, Winking J, Hooper P, and Stieglitz J. 2010. Learning, menopause, and the human adaptive complex. Annals of the New York Academy of Sciences 1204:30-42. 
1081

1082

1083

1084

1085

1086

1087

1088

1089

1090

1091

1092

1093

1094

1095

1096

1097

1098

1099

1100

1101

1102

Kaplan H, and Hill K. 1985. Food Sharing Among Ache Foragers: Tests of Explanatory

Hypotheses [and Comments and Reply]. Current Anthropology 26(2):223-246.

Kaplan H, Hill K, Lancaster J, and Hurtado A. 2000. A theory of human life history evolution: diet, intelligence, and longevity. Evolutionary Anthropology 9:156 - 185.

Kaplan H, Thompson RC, Trumble BC, Wann LS, Allam AH, Beheim B, Frohlich B, Sutherland ML, Sutherland JD, Stieglitz J et al. . 2017. Coronary atherosclerosis in indigenous South American Tsimane: a cross-sectional cohort study. Lancet 389(10080):1730-1739.

Kaplan HS, Hooper PL, and Gurven M. 2009. The evolutionary and ecological roots of human social organization. Philosophical Transactions of the Royal Society B: Biological Sciences 364(1533):3289-3299.

Kneissel M, Roschger P, Steiner W, Schamall D, Kalchhauser G, Boyde A, and Teschler-Nicola M. 1997. Cancellous bone structure in the growing and aging lumbar spine in a historic Nubian population. Calcif Tissue Int 61(2):95-100.

Konigsberg L, and Herrmann N. 2006. The osteological evidence for human longevity in the recent past. In: Hawkes K, and Paine R, editors. The Evolution of Human Life History. Santa Fe: School of American Research Press. p 267-306.

Koster J, McElreath R, Hill K, Yu D, Shepard G, van Vliet N, Gurven M, Trumble B, Bird RB, Bird D et al. . 2020. The life history of human foraging: Cross-cultural and individual variation. Science Advances 6(26):eaax9070.

Koster J, Mcelreath R, Hill K, Yu D, Shepard G, Vliet NV, Gurven M, Kaplan H, Trumble B, Bird RB et al. . 2019. The Life History Of Human Foraging: Cross-Cultural And Individual Variation. bioRxiv:574483. 
medRxiv preprint doi: https://doi.org/10.1101/2020.09.10.20191916; this version posted November 23, 2020. The copyright holder for this preprint (which was not certified by peer review) is the author/funder, who has granted medRxiv a license to display the preprint in perpetuity.

It is made available under a CC-BY-NC-ND 4.0 International license .

1103 Kraft TS, Stieglitz J, Trumble BC, Martin M, Kaplan H, and Gurven M. 2018. Nutrition

1104 transition in 2 lowland Bolivian subsistence populations. Am J Clin Nutr 108(6):1183-

1105 1195.

1106 Kralick AE, and Zemel BS. 2020. Evolutionary Perspectives on the Developing Skeleton and Implications for Lifelong Health. Frontiers in Endocrinology 11(99).

Kramer K. 2005. Children's help and the pace of reproduction: Cooperative breeding in humans. Evolutionary Anthropology 14:224 - 237.

Kuhn SL, and Stiner MC. 2019. Hearth and Home in the Middle Pleistocene. Journal of Anthropological Research 75(3):305-327.

Lambert PM, and Welker MH. 2017. Traumatic injury risk and agricultural transitions: A view from the American Southeast and beyond. American Journal of Physical Anthropology 162(1):120-142.

Lentle BC, Berger C, Probyn L, Brown JP, Langsetmo L, Fine B, Lian K, Shergill AK, Trollip J, Jackson S et al. . 2018. Comparative Analysis of the Radiology of Osteoporotic Vertebral Fractures in Women and Men: Cross-Sectional and Longitudinal Observations from the Canadian Multicentre Osteoporosis Study (CaMos). J Bone Miner Res 33(4):569-579. Lives. New York: Dutton. Vintage.

1123 Lieverse AR, Weber AW, Bazaliiskiy VI, Goriunova OI, and Savel'ev NA. 2007. Osteoarthritis in Siberia's Cis-Baikal: Skeletal indicators of hunter-gatherer adaptation and cultural change. Am J Phys Anthropol 132(1):1-16. 
medRxiv preprint doi: https://doi.org/10.1101/2020.09.10.20191916; this version posted November 23, 2020. The copyright holder for this preprint (which was not certified by peer review) is the author/funder, who has granted medRxiv a license to display the preprint in perpetuity.

It is made available under a CC-BY-NC-ND 4.0 International license .

1126 Lovejoy CO, and Heiple KG. 1981. The analysis of fractures in skeletal populations with an

1127

1128

1129

1130

1131

1132

1133

1134

1135

1136

1137

1138

1139

1140

1141

1142

1143

1144

1145

1146

1147

1148

example from the Libben site, Ottowa County, Ohio. American Journal of Physical Anthropology 55(4):529-541.

Lovell NC. 1990. Skeletal and dental pathology of free-ranging mountain gorillas. Am J Phys Anthropol 81(3):399-412.

Marlowe F. 2000. The patriarch hypothesis. Human Nature 11(1):27-42.

Marlowe F. 2003. A critical period for provisioning by Hadza men. Evolution and Human Behavior 24(3):217-229.

Mays S, Lees B, and Stevenson JC. 1998. Age-dependent bone loss in the femur in a medieval population. International Journal of Osteoarchaeology 8(2):97-106.

Mays SA. 1996. Age-dependent cortical bone loss in a medieval population. International Journal of Osteoarchaeology 6(2):144-154.

Meerding WJ, W IJ, Koopmanschap MA, Severens JL, and Burdorf A. 2005. Health problems lead to considerable productivity loss at work among workers with high physical load jobs. J Clin Epidemiol 58(5):517-523.

Migliano AB, Page AE, Gómez-Gardeñes J, Salali GD, Viguier S, Dyble M, Thompson J, Chaudhary N, Smith D, Strods J et al. . 2017. Characterization of hunter-gatherer networks and implications for cumulative culture. Nature Human Behaviour 1(2):0043.

Minichillo T. 2005. Paleodemography, grandmothering, and modern human evolution: a comment on Caspari and Lee (2004). Journal of Human Evolution 49(5):643-645.

Morbeck M, Galloway A, and Richman Sumner D. 2002. Getting old at Gombe: skeletal aging in wild-ranging chimpanzees. In: Erwin J, and Hof P, editors. Interdisciplinary Topics in Gerontology: Aging in Nonhuman Primates. Basel: Karger. p 48-62. 
medRxiv preprint doi: https://doi.org/10.1101/2020.09.10.20191916; this version posted November 23, 2020. The copyright holder for this preprint (which was not certified by peer review) is the author/funder, who has granted medRxiv a license to display the preprint in perpetuity.

It is made available under a CC-BY-NC-ND 4.0 International license .

1149 Mosekilde L. 1989. Sex differences in age-related loss of vertebral trabecular bone mass and

1150 structure_-biomechanical consequences. Bone 10(6):425-432.

1151 Mosekilde L, Mosekilde L, and Danielsen CC. 1987. Biomechanical competence of vertebral

1152 trabecular bone in relation to ash density and age in normal individuals. Bone 8(2):79-85.

1153 Myers ER, and Wilson SE. 1997. Biomechanics of osteoporosis and vertebral fracture. Spine $1154 \quad$ 22(24 Suppl):25s-31s.

1155 Nevitt MC, Ettinger B, Black DM, Stone K, Jamal SA, Ensrud K, Segal M, Genant HK, and Cummings SR. 1998. The association of radiographically detected vertebral fractures with back pain and function: a prospective study. Annals of internal medicine

1159 NIH Consensus Development Panel on Osteoporosis Prevention D, and Therapy. 2001. Osteoporosis prevention, diagnosis, and therapy. Jama 285(6):785-795.

O'Neill TW, Cockerill W, Matthis C, Raspe HH, Lunt M, Cooper C, Banzer D, Cannata JB, Naves M, Felsch B et al. . 2004. Back pain, disability, and radiographic vertebral fracture in European women: a prospective study. Osteoporos Int 15(9):760-765.

1164 Osipov B, Emami AJ, and Christiansen BA. 2018. Systemic Bone Loss After Fracture. Clin Rev Bone Miner Metab 16(4):116-130.

1166 Pfeiffer S. 2012. Two disparate instances of healed cranial trauma from the later stone age of South Africa. South African Archaeological Bulletin 67:256-261.

1168 Polga DJ, Beaubien BP, Kallemeier PM, Schellhas KP, Lew WD, Buttermann GR, and Wood 1169 KB. 2004. Measurement of in vivo intradiscal pressure in healthy thoracic intervertebral discs. Spine 29(12):1320-1324. 
medRxiv preprint doi: https://doi.org/10.1101/2020.09.10.20191916; this version posted November 23, 2020. The copyright holder for this preprint (which was not certified by peer review) is the author/funder, who has granted medRxiv a license to display the preprint in perpetuity.

It is made available under a CC-BY-NC-ND 4.0 International license .

1171 Pontzer H, Raichlen DA, and Sockol MD. 2009. The metabolic cost of walking in humans,

1172 chimpanzees, and early hominins. Journal of Human Evolution 56(1):43-54.

1173 Reinbold WD, Adler CP, Kalender WA, and Lente R. 1991. Accuracy of vertebral mineral 1174 determination by dual-energy quantitative computed tomography. Skeletal radiology

1175 20(1):25-29.

1176 Richerson PJ, and Boyd R. 2008. Not by genes alone: How culture transformed human evolution: University of Chicago Press.

1178 Rohlmann A, Claes LE, Bergmannt G, Graichen F, Neef P, and Wilke HJ. 2001. Comparison of 1179 intradiscal pressures and spinal fixator loads for different body positions and exercises.

Ryan CP, Hayes MG, Lee NR, McDade TW, Jones MJ, Kobor MS, Kuzawa CW, and Eisenberg DTA. 2018. Reproduction predicts shorter telomeres and epigenetic age acceleration among young adult women. Scientific Reports 8(1):11100.

1184 Sambrook P, and Cooper C. 2006. Osteoporosis. Lancet 367:2010-2018.

1185 Schniter E, Gurven M, Kaplan HS, Wilcox NT, and Hooper PL. 2015. Skill ontogeny among Tsimane forager-horticulturalists. American Journal of Physical Anthropology 158(1):3-

Schniter E, Wilcox NT, Beheim BA, Kaplan HS, and Gurven M. 2018. Information transmission and the oral tradition: Evidence of a late-life service niche for Tsimane Amerindians. Evolution and Human Behavior 39(1):94-105.

1191 Shepherd JA, Schousboe JT, Broy SB, Engelke K, and Leslie WD. 2015. Executive Summary of the 2015 ISCD Position Development Conference on Advanced Measures From DXA 
medRxiv preprint doi: https://doi.org/10.1101/2020.09.10.20191916; this version posted November 23, 2020. The copyright holder for this preprint (which was not certified by peer review) is the author/funder, who has granted medRxiv a license to display the preprint in perpetuity.

It is made available under a CC-BY-NC-ND 4.0 International license .

and QCT: Fracture Prediction Beyond BMD. Journal of clinical densitometry : the official journal of the International Society for Clinical Densitometry 18(3):274-286.

Stewart TD, and Hall RM. 2006. (iv) Basic biomechanics of human joints: Hips, knees and the spine. Current Orthopaedics 20(1):23-31.

Stieglitz J, Beheim BA, Trumble BC, Madimenos FC, Kaplan H, and Gurven M. 2015a. Low mineral density of a weight-bearing bone among adult women in a high fertility population. American Journal of Physical Anthropology 156:637-648.

Stieglitz J, Jaeggi A, Blackwell A, Trumble B, Gurven M, and Kaplan H. 2014. Work to live and live to work: Productivity, transfers, and psychological well-being in adulthood and old age. In: Weinstein M, and Lane M, editors. Sociality, Hierarchy, and Health: comparative biodemography. Washington DC: Committee on Population of the National Research Council, National Academies Press. p 197-221.

Stieglitz J, Madimenos F, Kaplan H, and Gurven M. 2016. Calcaneal Quantitative Ultrasound Indicates Reduced Bone Status Among Physically Active Adult Forager-Horticulturalists. Journal of Bone and Mineral Research 31(3):663-671.

Stieglitz J, Schniter E, von Rueden C, Kaplan H, and Gurven M. 2015b. Functional Disability and Social Conflict Increase Risk of Depression in Older Adulthood Among Bolivian Forager-Farmers. The Journals of Gerontology Series B: Psychological Sciences and Social Sciences 70(6):948-956.

Stieglitz J, Trumble B, Kaplan H, and Gurven M. 2017. Horticultural activity predicts later localized limb status in a contemporary pre-industrial population. American Journal of Physical Anthropology 163(3):425-436. 
medRxiv preprint doi: https://doi.org/10.1101/2020.09.10.20191916; this version posted November 23, 2020. The copyright holder for this preprint (which was not certified by peer review) is the author/funder, who has granted medRxiv a license to display the preprint in perpetuity.

It is made available under a CC-BY-NC-ND 4.0 International license .

1215 Stieglitz J, Trumble BC, Kaplan H, and Gurven M. 2018. Marital violence and fertility in a

1216

1217

1218

1219

1220

1221

1222

1223

1224

1225

1226

1227

1228

1229

1230

1231

1232

1233

1234 Thompson JC, Carvalho S, Marean CW, and Alemseged Z. 2019. Origins of the Human

1235

1236

relatively egalitarian high-fertility population. Nature Human Behaviour 2(8):565-572.

Stieglitz J, Trumble BC, Team HS, Finch CE, Li D, Budoff MJ, Kaplan H, and Gurven MD. 2019. Computed tomography shows high fracture prevalence among physically active forager-horticulturalists with high fertility. eLife 8:e48607.

Sugiyama L, and Chacon R. 2000. Effects of Illness and Injury on Foraging Among the Yora and Shiwiar: Pathology Risk as Adaptive Problem. In: Cronk L, Chagnon N, and Irons W, editors. Human Behavior and Adaptation: An Anthropological Perspective. New York: Aldine. p 371-395.

Sugiyama LS. 2004. Illness, injury, and disability among Shiwiar forager-horticulturalists: Implications of health-risk buffering for the evolution of human life history. American Journal of Physical Anthropology 123(4):371-389.

Sumner DR, Morbeck ME, and Lobick JJ. 1989. Apparent age-related bone loss among adult female Gombe chimpanzees. Am J Phys Anthropol 79(2):225-234.

Suzuki N, Ogikubo O, and Hansson T. 2008. The course of the acute vertebral body fragility fracture: its effect on pain, disability and quality of life during 12 months. European spine journal : official publication of the European Spine Society, the European Spinal Deformity Society, and the European Section of the Cervical Spine Research Society 17(10):1380-1390.

Predatory Pattern: The Transition to Large-Animal Exploitation by Early Hominins. Current Anthropology 60(1):1-23. 
medRxiv preprint doi: https://doi.org/10.1101/2020.09.10.20191916; this version posted November 23, 2020. The copyright holder for this preprint (which was not certified by peer review) is the author/funder, who has granted medRxiv a license to display the preprint in perpetuity.

It is made available under a CC-BY-NC-ND 4.0 International license .

1237 Tilley L. 2015. Theory and Practice in the Bioarchaeology of Care: Springer International

$1238 \quad$ Publishing.

1239 Trinkaus E. 1985. Pathology and the posture of the La Chapelle-aux-Saints Neandertal. Am J

1240 Phys Anthropol 67(1):19-41.

1241 Trinkaus E. 2018. An abundance of developmental anomalies and abnormalities in Pleistocene

1242 people. Proceedings of the National Academy of Sciences 115(47):11941-11946.

1243 Trumble BC, Cummings DK, O’Connor KA, Holman DJ, Smith EA, Kaplan HS, and Gurven

1244 MD. 2013. Age-independent increases in male salivary testosterone during horticultural

1245 activity among Tsimane forager-farmers. Evolution and Human Behavior 34(5):350-357.

1246 Trumble BC, Smith EA, O'Connor KA, Kaplan HS, and Gurven MD. 2014. Successful hunting

1247 increases testosterone and cortisol in a subsistence population. Proceedings of the Royal

1248 Society of London B: Biological Sciences 281(1776).

1249 Ungar PS. 2012. Dental Evidence for the Reconstruction of Diet in African Early

$1250 \quad<\mathrm{em}>$ Homo</em>. Current Anthropology 53(S6):S318-S329.

1251 Walker R, Hill K, Kaplan H, and McMillan G. 2002. Age-dependency in hunting ability among

1252 the Ache of eastern Paraguay. Journal of Human Evolution 42:639 - 657.

1253 Wallace IJ, Nesbitt A, Mongle C, Gould ES, and Grine FE. 2014. Age-related variation in limb 1254 bone diaphyseal structure among Inuit foragers from Point Hope, northern Alaska. Arch $1255 \quad$ Osteoporos 9(1):202.

1256 Washburn S, and Lancaster C. 1968a. The evolution of hunting. In: Lee R, and DeVore I, 1257 editors. Man the hunter. Chicago: Aldine. p 293-303.

1258 Washburn S, and Lancaster C. 1968b. The evolution of hunting. In: Lee R, and Devore I, editors. 1259 Man the Hunter. Chicago: Aldine. p 293-303. 
medRxiv preprint doi: https://doi.org/10.1101/2020.09.10.20191916; this version posted November 23, 2020. The copyright holder for this preprint (which was not certified by peer review) is the author/funder, who has granted medRxiv a license to display the preprint in perpetuity.

It is made available under a CC-BY-NC-ND 4.0 International license .

1260 Wood B, and K. Boyle E. 2016. Hominin taxic diversity: Fact or fantasy? American Journal of $1261 \quad$ Physical Anthropology 159(S61):37-78.

1262 Wood BM, and Marlowe FW. 2013. Household and kin provisioning by Hadza men. Human $1263 \quad$ Nature 24(3):280-317.

1264 Wood BM, Watts DP, Mitani JC, and Langergraber KE. 2017. Favorable ecological

1265 circumstances promote life expectancy in chimpanzees similar to that of human hunter1266 gatherers. J Hum Evol 105:41-56.

1267 Wrangham R, and Carmody R. 2010. Human adaptation to the control of fire. Evolutionary

1268 Anthropology: Issues, News, and Reviews 19(5):187-199.

1269 Ziomkiewicz A, Sancilio A, Galbarczyk A, Klimek M, Jasienska G, and Bribiescas RG. 2016.

1270 Evidence for the Cost of Reproduction in Humans: High Lifetime Reproductive Effort Is

1271 Associated with Greater Oxidative Stress in Post-Menopausal Women. PLOS ONE

$1272 \quad$ 11(1):e0145753.

1273

1274

1275

1276

1277

1278

1279

1280

1281

1282 


\section{Appendix}

\section{Methods}

\subsection{Study design and participants}

Since 2002 the Tsimane (pop. 16,000) have participated in the ongoing Tsimane Health and Life History Project (THLHP; see Gurven et al 2017 for an overview). All Tsimane residing in study villages are eligible to participate and most participate at least once. THLHP physicians have conducted annual medical exams on Tsimane of all ages since 2002. A mobile team of physicians and Tsimane research assistants collects data in villages on medical histories, functional ability, and aspects of lifestyle (e.g. food production and sharing).

Between July 2014 and September 2015, men and women age 40+ from 59 Tsimane villages were invited to participate in the CT scanning project. At the time, there were 1,214 eligible adults living in these villages (the only eligibility criteria were being $40+$ years old, selfidentifying as Tsimane and willing to participate). 731 adults were present in their villages at the time and subsequently received a CT scan. Transporting participants from their village to the nearby market town of San Borja was logistically complicated (requiring trekking through the forest, dug-out canoes, rafts propelled by poles pushed off the river bottom, trucks, and cars) and can require up to two days of travel each way. From San Borja to the Beni department capital of Trinidad (where the hospital containing the CT scanner is located) is an additional 6-hour car ride. Due to these logistical complications, participants not in their village at the time we arrived were not sampled. The Tsimane are semi-mobile and often build secondary houses deep in the forest near their horticultural plots, not returning to their village for extended periods of time. Hunting and fishing trips can last days or weeks, and some men engage in wage labor in San Borja or elsewhere (e.g. rural cattle ranches). In an average village, approximately one-third of individuals are away hunting, fishing, working in their horticultural plots, or in San Borja at any given time. Additionally, a major flood in February 2014 resulted in mass migration from some villages, and the creation of several new villages that were not sampled as part of this study, further reducing the number individuals that could be sampled in this study. To address potential sources of sample bias, analyses comparing Tsimane who received CTs and those who did not but who participated in the THLHP's medical exams in Tsimane villages were conducted. There were no significant differences in sex, blood pressure or body fat (see Kaplan et al 2017 for these and additional participant details) and thus the CT sample analyzed here is thought to be representative of all Tsimane age $40+$ years.

Of the 731 Tsimane who received a CT scan, CT data from 506 (69\%) were selected with no particular criteria to estimate thoracic vertebral body bone mineral density (BMD) and fracture prevalence and severity (radiologist time constraints precluded analysis of all 731 adults). Of the 506 Tsimane contributing BMD and fracture data, 14 (3\%) were missing data on subsistence involvement (e.g. whether still able to hunt or walk all day) because of absent or sick THLHP personnel who were unable to collect data, resulting in a final sample of 493 adults. Among these 493 adults, some anthropometric data were missing because of missing or broken equipment (see Appendix 1-table 1 for sample sizes and descriptives for study variables). 
Appendix 1-table 1. Descriptives for study variables ${ }^{\mathrm{a}}$.

\begin{tabular}{|c|c|c|c|c|c|}
\hline Variable & $\mathrm{N}$ & Mean & SD & Min & Max \\
\hline Thoracic vertebral body BMD (mg/cm³) & 493 & 165.5 & 41.3 & 68.9 & 315.0 \\
\hline Any thoracic vertebral body (T6-T12) fracture & & & & & \\
\hline (proportion grade $\geq 1$ ) & 493 & 0.28 & 0.45 & 0 & 1 \\
\hline Any thoracic vertebral body (T6-T12) fracture & & & & & \\
\hline (proportion grade $\geq 2$ ) & 493 & 0.09 & 0.29 & 0 & 1 \\
\hline Age (years) & 493 & 55.9 & 9.9 & 41.2 & 91.0 \\
\hline Sex (proportion male) & 493 & 0.52 & 0.5 & 0 & 1 \\
\hline Height (cm) & 489 & 156.1 & 7.6 & 136.0 & 176.3 \\
\hline Weight (kg) & 489 & 58.7 & 9.8 & 34.6 & 96.9 \\
\hline Body fat (\%) & 445 & 21.5 & 8.0 & 5.0 & 46.7 \\
\hline Fat mass (kg) & 445 & 12.9 & 6.1 & 1.9 & 42.1 \\
\hline Fat-free mass (kg) & 445 & 45.8 & 7.9 & 27.8 & 73.1 \\
\hline
\end{tabular}

${ }^{a}$ Data were missing for various reasons (see Appendix for details).

\subsection{Thoracic vertebral body bone mineral density (BMD)}

CT-measured vertebral body BMD is increasingly used for osteoporosis screening in vivo because of its ability to provide three-dimensional information compared to traditional dual x-ray absorptiometry two-dimensional images.

Intra-observer variability in BMD measurements using the same measurement technique in a different sample (see Budoff et al 2010) was tested on 120 scans by one radiologist, with 1week intervals between the two readings. To measure inter-observer variability on 67 randomly selected scans, the results obtained by two radiologists who were blinded to all clinical information were compared using this other sample. Intra- and inter-observer variations in BMD measurements were $2.5 \%$ and $2.6 \%$, respectively.

\subsection{Thoracic vertebral body fracture}

Genant's semi-quantitative technique does not distinguish between wedge (i.e. reduced anterior height), biconcave (i.e. reduced central height) or crush (i.e. reduced posterior height) fractures; most fractures contain a combination of these features and are influenced by the local biomechanics of the spinal level involved. Vertebral body fractures are differentiated from other, non-fracture deformities (e.g. osteoarthritis), although these other deformities were not systematically coded.

\subsection{Socio-demographics and anthropometrics}

Birth years were assigned based on a combination of methods described in detail elsewhere (Gurven et al 2007), including using known ages from written records, relative age lists, dated events, photo comparisons of people with known ages, and cross-validation of information from independent interviews of kin. Each method provides an independent estimate of age, and when estimates yielded a date of birth within a three-year range, the average was generally used. 
medRxiv preprint doi: https://doi.org/10.1101/2020.09.10.20191916; this version posted November 23, 2020. The copyright holder for this preprint (which was not certified by peer review) is the author/funder, who has granted medRxiv a license to display the preprint in perpetuity.

It is made available under a CC-BY-NC-ND 4.0 International license .

1357

1358

1359

1360

1361

1362

1363

1364

1365

1366

1367

1368

1369

1370

1371

1372

1373

1374

1375

1376

1377

\section{Results}

3.2. Hunting cessation is associated with thoracic vertebral body fracture and, albeit weakly, with lower BMD

Appendix 1-table 2. Percentage of men (95\% CI) who completely ceased hunting by age and thoracic vertebral body fracture status (fracture grade $\geq 2$ ).

\begin{tabular}{lllll}
\hline $\begin{array}{l}\text { Age category } \\
\text { (years) }\end{array}$ & $\begin{array}{l}\text { \% ceased hunting } \\
\text { with fracture }\end{array}$ & $\mathrm{N}$ & $\begin{array}{l}\text { \% ceased hunting } \\
\text { without fracture }\end{array}$ & $\mathrm{N}$ \\
\hline $40-49$ & $0(----)$ & 4 & $3(<1-6)$ & 77 \\
$50-59$ & $21(<1-46)$ & 14 & $14(6-22)$ & 78 \\
$60-69$ & $60(<1-1)$ & 5 & $32(19-45)$ & 50 \\
$70+$ & $100(---)$ & $6^{\text {a }}$ & $73(53-93)$ & $22^{\mathrm{b}}$ \\
Total & $41^{* *}(22-60)$ & 29 & $20(15-25)$ & 227 \\
\hline
\end{tabular}

${ }^{\hat{\mathrm{p}} \leq 0.1} \quad{ }^{*} \mathrm{p} \leq 0.05 \quad{ }^{* *} \mathrm{p} \leq 0.01 \quad{ }^{* * *} \mathrm{p} \leq 0.001$ ( $\chi^{2}$ or Fisher's Exact Test [vs. no fracture]).

${ }^{\mathrm{a}}$ Max age $=83$ years $(\mathrm{Mean} \pm \mathrm{SD}=74 \pm 4)$.

${ }^{b}$ Max age $=83$ years $($ Mean $\pm S D=74 \pm 3)$.

Appendix 1-table 3. Binary logistic regression: effect of thoracic vertebral body fracture on the probability of hunting cessation after adjusting for age (model 1; n=256 men). Model 2

additionally includes as a covariate thoracic vertebral body BMD. Shown are odds ratios (95\% CIs); continuous variables are z-scored.

\begin{tabular}{|c|c|c|}
\hline Parameter & Model 1 & $\begin{array}{l}\text { Model } 2 \\
(+ \text { BMD) }\end{array}$ \\
\hline Any thoracic vertebral body fracture (grade $\geq 1$; vs. none) & $7.3^{* * *}(3.3-17.6)$ & $7.4^{* * *}(3.3-18.2)$ \\
\hline Age (years) & $5.2^{* * *}(3.4-8.5)$ & $4.1^{* * *}(2.5-7.0)$ \\
\hline Thoracic vertebral body BMD (mg/ $\left.\mathrm{cm}^{3}\right)$ & ----- & $0.62^{*}(0.38-0.99)$ \\
\hline AIC & 178.55 & 176.61 \\
\hline
\end{tabular}


medRxiv preprint doi: https://doi.org/10.1101/2020.09.10.20191916; this version posted November 23, 2020. The copyright holder for this preprint (which was not certified by peer review) is the author/funder, who has granted medRxiv a license to display the preprint in perpetuity.

It is made available under a CC-BY-NC-ND 4.0 International license .

\subsection{Hunting cessation associated with thoracic vertebral body fracture and lower BMD generates substantial productivity losses}

\subsubsection{Fracture.}

Appendix 1-table 4. Tsimane men's age-specific daily hunting production by thoracic vertebral body fracture status.

\begin{tabular}{|c|c|c|c|c|c|}
\hline $\begin{array}{l}\text { Age } \\
\text { (years) }\end{array}$ & $\begin{array}{l}\text { A) Hunt } \\
\text { cals/day }\end{array}$ & $\begin{array}{l}\text { B) Probability still } \\
\text { hunting: no fracture }\end{array}$ & $\begin{array}{l}\text { C) Probability still } \\
\text { hunting: fracture }\end{array}$ & $\begin{array}{l}\text { D) Hunt cals/day: } \\
\text { no fracture }{ }^{\mathrm{c}}\end{array}$ & $\begin{array}{l}\text { E) Hunt cals/day: } \\
\text { fracture }^{\mathrm{d}}\end{array}$ \\
\hline 40 & 1872 & 0.995 & 0.968 & 1864 & 1812 \\
\hline 41 & 1884 & 0.995 & 0.962 & 1874 & 1813 \\
\hline 42 & 1888 & 0.994 & 0.955 & 1875 & 1803 \\
\hline 43 & 1882 & 0.992 & 0.947 & 1868 & 1783 \\
\hline 44 & 1870 & 0.991 & 0.938 & 1853 & 1754 \\
\hline 45 & 1855 & 0.989 & 0.927 & 1835 & 1720 \\
\hline 46 & 1836 & 0.987 & 0.915 & 1813 & 1680 \\
\hline 47 & 1815 & 0.985 & 0.900 & 1787 & 1634 \\
\hline 48 & 1790 & 0.982 & 0.884 & 1758 & 1582 \\
\hline 49 & 1762 & 0.979 & 0.865 & 1725 & 1524 \\
\hline 50 & 1731 & 0.975 & 0.843 & 1687 & 1459 \\
\hline 51 & 1697 & 0.970 & 0.819 & 1646 & 1389 \\
\hline 52 & 1659 & 0.965 & 0.792 & 1601 & 1314 \\
\hline 53 & 1619 & 0.958 & 0.762 & 1551 & 1233 \\
\hline 54 & 1575 & 0.951 & 0.729 & 1498 & 1148 \\
\hline 55 & 1528 & 0.942 & 0.694 & 1440 & 1060 \\
\hline 56 & 1478 & 0.932 & 0.656 & 1378 & 969 \\
\hline 57 & 1425 & 0.920 & 0.616 & 1311 & 878 \\
\hline 58 & 1369 & 0.906 & 0.574 & 1241 & 786 \\
\hline 59 & 1310 & 0.891 & 0.531 & 1166 & 696 \\
\hline 60 & 1247 & 0.873 & 0.488 & 1088 & 609 \\
\hline 61 & 1181 & 0.852 & 0.445 & 1007 & 526 \\
\hline 62 & 1113 & 0.829 & 0.403 & 923 & 449 \\
\hline 63 & 1041 & 0.803 & 0.362 & 836 & 377 \\
\hline 64 & 966 & 0.775 & 0.323 & 748 & 313 \\
\hline 65 & 888 & 0.743 & 0.287 & 660 & 255 \\
\hline 66 & 807 & 0.709 & 0.253 & 572 & 204 \\
\hline 67 & 723 & 0.672 & 0.222 & 486 & 160 \\
\hline 68 & 636 & 0.633 & 0.193 & 402 & 123 \\
\hline 69 & 546 & 0.592 & 0.168 & 323 & 92 \\
\hline 70 & 452 & 0.549 & 0.145 & 249 & 66 \\
\hline 71 & 356 & 0.506 & 0.125 & 180 & 44 \\
\hline 72 & 257 & 0.463 & 0.107 & 119 & 28 \\
\hline 73 & 154 & 0.421 & 0.092 & 65 & 14 \\
\hline 74 & 49 & 0.379 & 0.078 & 19 & 4 \\
\hline 75 & 0 & 0.339 & 0.067 & 0 & 0 \\
\hline 76 & 0 & 0.302 & 0.057 & 0 & 0 \\
\hline 77 & 0 & 0.267 & 0.048 & 0 & 0 \\
\hline 78 & 0 & 0.234 & 0.041 & 0 & 0 \\
\hline 79 & 0 & 0.205 & 0.035 & 0 & 0 \\
\hline 80 & 0 & 0.178 & 0.029 & 0 & 0 \\
\hline
\end{tabular}

aPredicted values (loess fit). From Jan 2005-Dec 2009 adults were interviewed once or twice per week about time allocation and production for each co-resident individual over age six during the previous two days ( $\mathrm{n}=1,245$ individuals from 11 villages). 
medRxiv preprint doi: https://doi.org/10.1101/2020.09.10.20191916; this version posted November 23, 2020. The copyright holder for this

preprint (which was not certified by peer review) is the author/funder, who has granted medRxiv a license to display the preprint in perpetuity.

It is made available under a CC-BY-NC-ND 4.0 International license .

1402 3.3.2. Lower BMD.

1403

1404 Appendix 1-table 5. Tsimane men's age-specific daily hunting production by thoracic vertebral body 1405 fracture status and thoracic vertebral body bone mineral density (BMD). For illustrative purposes we report 1406 estimates holding BMD at +1 SD and -1 SD of the mean.

\begin{tabular}{|c|c|c|c|c|c|c|c|c|c|}
\hline $\begin{array}{l}\text { Age } \\
\text { (years) }\end{array}$ & $\begin{array}{l}\text { A) Hunt } \\
\text { cals/day }^{\mathrm{a}}\end{array}$ & $\begin{array}{l}\text { B) Probability } \\
\text { still hunting: } \\
\text { no fracture and } \\
+1 \mathrm{SD} \mathrm{BMD}^{\mathrm{b}}\end{array}$ & $\begin{array}{l}\text { C) Probability } \\
\text { still hunting: } \\
\text { no fracture and } \\
-1 \text { SD BMD }^{\mathrm{b}}\end{array}$ & $\begin{array}{l}\text { D) Probability } \\
\text { still hunting: } \\
\text { fracture and } \\
+1 \mathrm{SD} \mathrm{BMD}^{\mathrm{b}}\end{array}$ & $\begin{array}{l}\text { E) Probability } \\
\text { still hunting: } \\
\text { fracture and } \\
-1 \mathrm{SD}^{\mathrm{B}} \mathrm{BD}^{\mathrm{b}}\end{array}$ & $\begin{array}{l}\text { F) Hunt } \\
\text { cals/day: } \\
\text { no fracture } \\
\text { and }+1 \text { SD } \\
\text { BMD }^{c}\end{array}$ & $\begin{array}{l}\text { G) Hunt } \\
\text { cals/day: } \\
\text { no fracture } \\
\text { and }-1 \text { SD } \\
\text { BMD }^{\text {d }}\end{array}$ & $\begin{array}{l}\text { H) Hunt } \\
\text { cals/day: } \\
\text { fracture } \\
\text { and }+1 \text { SD } \\
\text { BMD }^{\text {e }}\end{array}$ & $\begin{array}{l}\text { I) Hunt } \\
\text { cals/day: } \\
\text { fracture } \\
\text { and -1 SD } \\
\text { BMD }^{\text {f }}\end{array}$ \\
\hline 40 & 1872 & 0.996 & 0.990 & 0.971 & 0.930 & 1865 & 1853 & 1819 & 1741 \\
\hline 41 & 1884 & 0.995 & 0.988 & 0.967 & 0.920 & 1875 & 1862 & 1822 & 1732 \\
\hline 42 & 1888 & 0.995 & 0.987 & 0.962 & 0.908 & 1878 & 1863 & 1816 & 1714 \\
\hline 43 & 1882 & 0.994 & 0.984 & 0.956 & 0.895 & 1870 & 1853 & 1800 & 1684 \\
\hline 44 & 1870 & 0.993 & 0.982 & 0.950 & 0.880 & 1857 & 1836 & 1776 & 1646 \\
\hline 45 & 1855 & 0.992 & 0.979 & 0.942 & 0.864 & 1840 & 1816 & 1747 & 1602 \\
\hline 46 & 1836 & 0.990 & 0.976 & 0.933 & 0.845 & 1819 & 1792 & 1714 & 1552 \\
\hline 47 & 1815 & 0.989 & 0.972 & 0.924 & 0.825 & 1795 & 1764 & 1676 & 1497 \\
\hline 48 & 1790 & 0.987 & 0.968 & 0.913 & 0.802 & 1767 & 1732 & 1633 & 1436 \\
\hline 49 & 1762 & 0.985 & 0.963 & 0.900 & 0.778 & 1736 & 1697 & 1586 & 1371 \\
\hline 50 & 1731 & 0.983 & 0.957 & 0.886 & 0.751 & 1701 & 1657 & 1533 & 1301 \\
\hline 51 & 1697 & 0.980 & 0.951 & 0.870 & 0.723 & 1664 & 1614 & 1476 & 1226 \\
\hline 52 & 1659 & 0.977 & 0.943 & 0.852 & 0.692 & 1621 & 1565 & 1414 & 1148 \\
\hline 53 & 1619 & 0.974 & 0.935 & 0.833 & 0.660 & 1576 & 1514 & 1348 & 1068 \\
\hline 54 & 1575 & 0.970 & 0.925 & 0.811 & 0.626 & 1527 & 1458 & 1278 & 986 \\
\hline 55 & 1528 & 0.965 & 0.915 & 0.788 & 0.591 & 1474 & 1397 & 1203 & 902 \\
\hline 56 & 1478 & 0.960 & 0.902 & 0.762 & 0.554 & 1418 & 1334 & 1126 & 819 \\
\hline 57 & 1425 & 0.953 & 0.888 & 0.734 & 0.518 & 1359 & 1266 & 1046 & 738 \\
\hline 58 & 1369 & 0.946 & 0.873 & 0.704 & 0.481 & 1296 & 1195 & 964 & 658 \\
\hline 59 & 1310 & 0.938 & 0.856 & 0.672 & 0.444 & 1229 & 1121 & 881 & 582 \\
\hline 60 & 1247 & 0.929 & 0.836 & 0.639 & 0.408 & 1159 & 1043 & 797 & 509 \\
\hline 61 & 1181 & 0.919 & 0.815 & 0.604 & 0.373 & 1085 & 963 & 714 & 440 \\
\hline 62 & 1113 & 0.907 & 0.792 & 0.568 & 0.339 & 1010 & 881 & 633 & 377 \\
\hline 63 & 1041 & 0.894 & 0.766 & 0.532 & 0.307 & 931 & 798 & 554 & 319 \\
\hline 64 & 966 & 0.879 & 0.739 & 0.495 & 0.276 & 849 & 714 & 478 & 267 \\
\hline 65 & 888 & 0.862 & 0.709 & 0.458 & 0.248 & 766 & 630 & 407 & 220 \\
\hline 66 & 807 & 0.844 & 0.678 & 0.422 & 0.221 & 681 & 547 & 340 & 178 \\
\hline 67 & 723 & 0.823 & 0.645 & 0.386 & 0.197 & 595 & 466 & 279 & 142 \\
\hline 68 & 636 & 0.801 & 0.610 & 0.352 & 0.174 & 509 & 388 & 224 & 111 \\
\hline 69 & 546 & 0.776 & 0.575 & 0.319 & 0.154 & 424 & 314 & 174 & 84 \\
\hline 70 & 452 & 0.750 & 0.538 & 0.288 & 0.136 & 339 & 243 & 130 & 61 \\
\hline 71 & 356 & 0.721 & 0.501 & 0.258 & 0.119 & 257 & 178 & 92 & 42 \\
\hline 72 & 257 & 0.690 & 0.464 & 0.231 & 0.105 & 177 & 119 & 59 & 27 \\
\hline 73 & 154 & 0.658 & 0.428 & 0.206 & 0.092 & 101 & 66 & 32 & 14 \\
\hline 74 & 49 & 0.624 & 0.392 & 0.183 & 0.080 & 31 & 19 & 9 & 4 \\
\hline 75 & 0 & 0.588 & 0.358 & 0.162 & 0.070 & 0 & 0 & 0 & 0 \\
\hline 76 & 0 & 0.552 & 0.324 & 0.143 & 0.061 & 0 & 0 & 0 & 0 \\
\hline 77 & 0 & 0.515 & 0.293 & 0.125 & 0.053 & 0 & 0 & 0 & 0 \\
\hline 78 & 0 & 0.479 & 0.263 & 0.110 & 0.046 & 0 & 0 & 0 & 0 \\
\hline 79 & 0 & 0.442 & 0.236 & 0.096 & 0.040 & 0 & 0 & 0 & 0 \\
\hline 80 & 0 & 0.406 & 0.210 & 0.084 & 0.035 & 0 & 0 & 0 & 0 \\
\hline $\begin{array}{l}1407 \\
1408\end{array}$ & \multicolumn{9}{|c|}{$\begin{array}{l}\text { aPredicted values (loess fit). From Jan 2005-Dec } 2009 \text { adults were interviewed once or twice per week about time allocation and production for } \\
\text { each co-resident individual over age six during the previous two days ( } \mathrm{n}=1,245 \text { individuals from } 11 \text { villages). }\end{array}$} \\
\hline 1409 & \multirow{5}{*}{\multicolumn{9}{|c|}{ 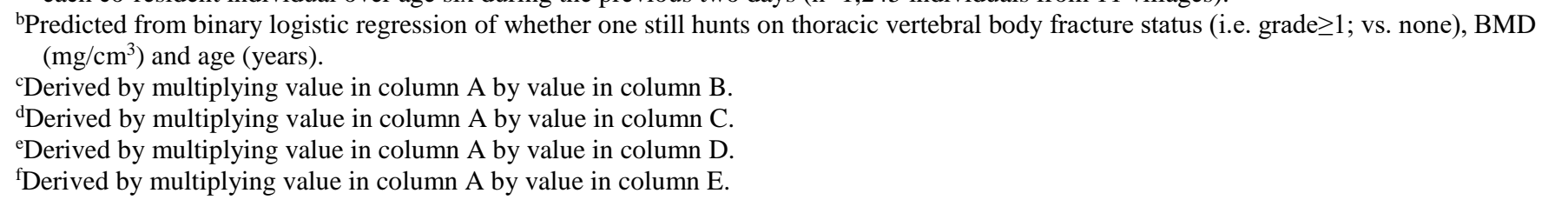 }} \\
\hline 1411 & & & & & & & & & \\
\hline 1412 & & & & & & & & & \\
\hline 1413 & & & & & & & & & \\
\hline 1414 & & & & & & & & & \\
\hline & & & & & & & & & \\
\hline
\end{tabular}


medRxiv preprint doi: https://doi.org/10.1101/2020.09.10.20191916; this version posted November 23, 2020. The copyright holder for this preprint (which was not certified by peer review) is the author/funder, who has granted medRxiv a license to display the preprint in perpetuity.

It is made available under a CC-BY-NC-ND 4.0 International license .

\subsection{Tree chopping cessation is associated with thoracic vertebral body fracture but not lower} $B M D$

Appendix 1-table 6. Binary logistic regression: effect of thoracic vertebral body fracture on the probability of tree chopping cessation after adjusting for age (model 1; n=256 men). Model 2 additionally includes as a covariate thoracic vertebral body BMD. Shown are odds ratios (95\% CIs); continuous variables are z-scored.

\begin{tabular}{|c|c|c|}
\hline Parameter & Model 1 & $\begin{array}{l}\text { Model } 2 \\
(+\mathrm{BMD})\end{array}$ \\
\hline Any thoracic vertebral body fracture (grade $\geq 1$; vs. none) & $6.9^{* * *}(3.1-16.6)$ & $6.8^{* * *}(3.1-16.6)$ \\
\hline Age (years) & $8.0^{* * *}(4.9-13.9)$ & $6.8^{* * *}(4.0-12.4)$ \\
\hline Thoracic vertebral body BMD $\left(\mathrm{mg} / \mathrm{cm}^{3}\right)$ & ----- & $0.75(0.47-1.16)$ \\
\hline AIC & 183.41 & 183.75 \\
\hline
\end{tabular}

3.5. Weaving cessation is not associated with thoracic vertebral body fracture but is associated, albeit weakly, with lower BMD

Appendix 1-table 7. Binary logistic regression: effect of thoracic vertebral body fracture on the probability of weaving cessation after adjusting for age (model 1; n=237 women). Model 2 additionally includes as a covariate thoracic vertebral body BMD. Shown are odds ratios (95\% CIs); continuous variables are z-scored.

\begin{tabular}{|c|c|c|}
\hline Parameter & Model 1 & $\begin{array}{l}\text { Model } 2 \\
(+\mathrm{BMD})\end{array}$ \\
\hline Any thoracic vertebral body fracture (grade $\geq 1$; vs. none) & $2.2(0.8-6.4)$ & $1.8(0.6-5.4)$ \\
\hline Age (years) & $4.9^{* * *}(3.1-8.6)$ & $3.3^{* * *}(1.8-6.6)$ \\
\hline Thoracic vertebral body BMD (mg/ $\left.\mathrm{cm}^{3}\right)$ & ----- & $0.51^{\wedge}(0.23-1.05)$ \\
\hline AIC & 134.52 & 133.18 \\
\hline
\end{tabular}

Appendix 1-table 8. Self-reported reasons for weaving cessation by thoracic vertebral body fracture status. Shown are percentages of women reporting a given reason.

\begin{tabular}{llll}
\hline Reason for weaving cessation & $\begin{array}{l}\text { Fracture } \\
(\mathrm{n}=9)\end{array}$ & $\begin{array}{l}\text { No fracture } \\
(\mathrm{n}=24)\end{array}$ & $\begin{array}{l}\text { Total } \\
(\mathrm{n}=33)\end{array}$ \\
\hline Problem with hips & 100 & 100 & 100 \\
Problem with back & 100 & 100 & 100 \\
Problem with fingers & 100 & 100 & 100 \\
Problem with hands (other than fingers) & 100 & 100 & 100 \\
Any problem with hips, back or hands & 100 & 100 & 100 \\
Difficulty sitting & 100 & 100 & 100 \\
Difficulty seeing & 89 & 88 & 88 \\
\hline
\end{tabular}

${ }^{\mathrm{p}} \leq 0.1 \quad{ }^{*} \mathrm{p} \leq 0.05 \quad{ }^{* *} \mathrm{p} \leq 0.01 \quad{ }^{* * *} \mathrm{p} \leq 0.001\left(\chi^{2}\right.$ or Fisher's Exact test [vs. no fracture]) 
medRxiv preprint doi: https://doi.org/10.1101/2020.09.10.20191916; this version posted November 23, 2020. The copyright holder for this preprint (which was not certified by peer review) is the author/funder, who has granted medRxiv a license to display the preprint in perpetuity.

It is made available under a CC-BY-NC-ND 4.0 International license .

3.6. Restricted day range is associated with thoracic vertebral body fracture and, albeit weakly, with lower BMD

Appendix 1-table 9. Binary logistic regression: effect of thoracic vertebral body fracture on the probability of not being able to walk a full day after adjusting for age and sex (model 1; n=493 adults). Model 2 additionally includes as a covariate thoracic vertebral body BMD. Shown are odds ratios (95\% CIs); continuous variables are z-scored. Interaction terms between sex and either fracture, age or BMD do not yield significant parameter estimates and are not shown.

\begin{tabular}{|c|c|c|}
\hline Parameter & Model 1 & $\begin{array}{l}\text { Model } 2 \\
\text { (+ BMD) }\end{array}$ \\
\hline Any thoracic vertebral body fracture (grade $\geq 1$; vs. none) & $8.2^{* * *}(4.8-14.5)$ & $7.8^{* * *}(4.5-13.8)$ \\
\hline Age (years) & $4.0^{* * *}(3.1-5.4)$ & $3.4^{* * *}(2.4-4.8)$ \\
\hline Sex=male & $0.19^{* * *}(0.11-0.31)$ & $0.21^{* * *}(0.12-0.34)$ \\
\hline Thoracic vertebral body BMD $\left(\mathrm{mg} / \mathrm{cm}^{3}\right)$ & ----- & $0.77^{\wedge}(0.57-1.03)$ \\
\hline AIC & 479.60 & 478.52 \\
\hline
\end{tabular}

\subsection{Suggestive evidence of fracture preceding task cessation, rather than the reverse}

Appendix 1-table 10. Self-reported reasons for hunting cessation by thoracic vertebral body fracture status. Shown are percentages of men reporting a given reason.

\begin{tabular}{llll}
\hline Reason for hunting cessation & $\begin{array}{l}\text { Fracture } \\
(\mathrm{n}=34)\end{array}$ & $\begin{array}{l}\text { No fracture } \\
(\mathrm{n}=22)\end{array}$ & $\begin{array}{l}\text { Total } \\
\left(\mathrm{n}=56^{\mathrm{a}}\right)\end{array}$ \\
\hline Problem with hips & $29^{* * \mathrm{~b}}$ & 0 & 18 \\
Problem with back & 53 & 59 & 55 \\
Problem with arms & 12 & 23 & 16 \\
Problem with legs & 56 & 55 & 55 \\
Any problem with hips, back or limbs & 77 & 86 & 80 \\
Feels weak & $29^{\wedge}$ & 50 & 38 \\
Tires easily & 59 & 64 & 61 \\
Tires easily or feels weak & 65 & 77 & 70 \\
Difficulty hearing & 38 & 50 & 43 \\
Difficulty seeing & 62 & 77 & 68 \\
Difficulty hearing or seeing & 65 & 82 & 71 \\
\hline
\end{tabular}

${ }^{a}$ Fracture data are missing for one man. For another man self-reported data are missing. ${ }^{b}$ FDR q $=0.012$.

Note: only q-values $\leq 0.05$ are reported. 
It is made available under a CC-BY-NC-ND 4.0 International license .

Appendix 1-table 11. Self-reported reasons for tree chopping cessation by thoracic vertebral body fracture status. Shown are percentages of men reporting a given reason.

\begin{tabular}{llll}
\hline Reason for tree chopping cessation & $\begin{array}{l}\text { Fracture } \\
(\mathrm{n}=41)\end{array}$ & $\begin{array}{l}\text { No fracture } \\
(\mathrm{n}=35)\end{array}$ & $\begin{array}{l}\text { Total } \\
\left(\mathrm{n}=76^{\mathrm{a}}\right)\end{array}$ \\
\hline Problem with hips & $29^{* \mathrm{~b}}$ & 9 & 20 \\
Problem with back & 59 & 71 & 64 \\
Problem with arms & $66^{\wedge}$ & 83 & 74 \\
Problem with legs & 29 & 26 & 28 \\
Any problem with hips, back or limbs & 83 & 94 & 88 \\
Feels weak & 54 & 54 & 54 \\
Tires easily & 63 & 71 & 67 \\
Tires easily or feels weak & 80 & 83 & 82 \\
\hline
\end{tabular}

${ }_{\mathrm{p}}^{\mathrm{p} \leq 0.1} \quad{ }^{*} \mathrm{p} \leq 0.05 \quad{ }^{* *} \mathrm{p} \leq 0.01{ }^{* * *} \mathrm{p} \leq 0.001$ ( $\chi^{2}$ or Fisher's Exact test [vs. no fracture]).

${ }^{a}$ Fracture data are missing for one man. For another man self-reported data are missing.

${ }^{\mathrm{b}}$ FDR q=0.036.

Note: only q-values $\leq 0.05$ are reported.

Appendix 1-table 12. Self-reported reasons for inability to walk all day by thoracic vertebral body fracture status. Shown are percentages of adults (pooled sexes) reporting a given reason.

\begin{tabular}{|c|c|c|c|}
\hline Reason for inability to walk all day & $\begin{array}{l}\text { Fracture } \\
(\mathrm{n}=95)\end{array}$ & $\begin{array}{l}\text { No fracture } \\
(n=134)\end{array}$ & $\begin{array}{l}\begin{array}{l}\text { Total } \\
\left(n=229^{a}\right)\end{array} \\
\end{array}$ \\
\hline Problem with hips & 39 & 39 & 39 \\
\hline Problem with back & 61 & 69 & 66 \\
\hline Problem with arms & 8 & 8 & 8 \\
\hline Problem with legs & 81 & 86 & 84 \\
\hline Any problem with hips, back or limbs & 88 & 93 & 91 \\
\hline Feels weak & 29 & 31 & 31 \\
\hline Tires easily & 71 & 60 & 65 \\
\hline Tires easily or feels weak & 76 & 69 & 72 \\
\hline
\end{tabular}

\section{References}

Budoff MJ, Hamirani YS, Gao YL, Ismaeel H, Flores FR, Child J, Carson S, Nee JN, and Mao S. 2010. Measurement of thoracic bone mineral density with quantitative CT. Radiology 257(2):434-440.

Gurven M, Kaplan H, and Zelada Supa A. 2007. Mortality experience of Tsimane Amerindians of Bolivia: Regional variation and temporal trends. American Journal of Human Biology 19:376 - 398.

Gurven M, Stieglitz J, Trumble B, Blackwell AD, Beheim B, Davis H, Hooper P, and Kaplan H. 2017. The Tsimane Health and Life History Project: Integrating anthropology and biomedicine. Evolutionary Anthropology 26(2):54-73.

Kaplan H, Thompson RC, Trumble BC, Wann LS, Allam AH, Beheim B, Frohlich B, Sutherland ML, Sutherland JD, Stieglitz J et al. . 2017. Coronary atherosclerosis in indigenous South American Tsimane: a cross-sectional cohort study. Lancet 389(10080):1730-1739. 